\title{
Authority and Power in Social Interaction
}

Authority and Power in Social Interaction explores methods of analyzing authority and power in the minutiae of interaction. Drawing on the expertise of a diverse international team of organizational communication and language and social interaction scholars, this book suggests reverting the perspective that notions of authority and power constrain human activity, to determine how people (re)create them through conversation and other joint action.

Confronting several perspectives within each chapter, the book offers a broad range of approaches to each theme: how and when to bring "context" into the analysis, formal authority, institutions, bodies and materiality, immateriality, and third parties. A core belief of this volume is that authority and power are not looming over human activity; rather, we weave together the constraints that we mutually impose on each other. Observing the details of how this joint process takes place may at once better account for how authority and power emerge and impact our actions, and provide guidelines on how to resist them.

This book will be an important reference for students and scholars in language and social interaction, organizational communication, as well as those interested in an alternative take on issues of authority and power. It will also find resonance among those interested in managements studies, public administration and other disciplines concerned with situations where authority is a crucial issue.

Nicolas Bencherki is an associate professor of organizational communication at TÉLUQ Montréal. His research focuses on the intersecting roles of organizational communication and materiality in the interactional constitution of membership, strategy and other conventional organizational issues in the setting of non-profit and community-based organizations, with a special interest for the concept of property.

Frédérik Matte is an assistant professor of communication at University of Ottawa, Canada. He studies tensions in the extreme and emergency situations faced by international non-governmental organizations (INGOs). He is interested in patient caring relationships, organizational change, intercultural settings and multi-lingual environments as well as ethical issues.

François Cooren, $\mathrm{PhD}$, is a professor at the Université de Montréal, Canada. His research focuses on organizational communication, language and social interaction, as well as communication theory. In 2010-2011, he was the president of the International Communication Association (ICA) and was elected fellow of this association in 2013. He is also the current president of the International Association for Dialogue Analysis (IADA, 2012-2019), as well as a Distinguished Scholar of the National Communication Association. 


\section{Routledge Studies in Communication, Organization, and Organizing}

Series Editor:

François Cooren

The goal of this series is to publish original research in the field of organizational communication, with a particular-but not exclusive-focus on the constitutive or performative aspects of communication. In doing so, this series aims to be an outlet for cutting-edge research monographs, edited books, and handbooks that will redefine, refresh and redirect scholarship in this field.

The volumes published in this series address topics as varied as branding, spiritual organizing, collaboration, employee communication, corporate authority, organizational timing and spacing, organizational change, organizational sense making, organization membership, and disorganization. What unifies this diversity of themes is the authors' focus on communication, especially in its constitutive and performative dimensions. In other words, authors are encouraged to highlight the key role communication plays in all these processes.

Methodological and Ontological Principles of Observation and Analysis Following and Analyzing Things and Beings in Our Everyday World Edited by François Cooren and Fabienne Malbois

\section{Dis/Organization as Communication}

Exploring the Disordering, Disruptive and Chaotic Properties of Communication

Edited by Consuelo Vásquez and Tim Kubn

\section{Authority and Power in Social Interaction}

Methods and Analysis

Edited by Nicolas Bencherki, Frédérik Matte and François Cooren

For more information about this series, please visit: www.routledge.com/ Routledge-Studies-in-Communication-Organization-and-Organizing/ book-series/RSCOO 


\section{Authority and Power in Social Interaction \\ Methods and Analysis}

Edited by Nicolas Bencherki, Frédérik Matte and François Cooren 
First published 2020

by Routledge

52 Vanderbilt Avenue, New York, NY 10017

and by Routledge

2 Park Square, Milton Park, Abingdon, Oxon, OX14 4RN

Routledge is an imprint of the Taylor \& Francis Group, an informa business

(C) 2020 Taylor \& Francis

The right of Nicolas Bencherki, Frédérik Matte and François Cooren to be identified as the authors of the editorial material, and of the authors for their individual chapters, has been asserted in accordance with sections 77 and 78 of the Copyright, Designs and Patents Act 1988.

All rights reserved. No part of this book may be reprinted or reproduced or utilised in any form or by any electronic, mechanical, or other means, now known or hereafter invented, including photocopying and recording, or in any information storage or retrieval system, without permission in writing from the publishers.

Trademark notice: Product or corporate names may be trademarks or registered trademarks, and are used only for identification and explanation without intent to infringe.

Library of Congress Cataloging-in-Publication Data

A catalog record for this book has been requested

ISBN: 978-1-138-48459-7 (hbk)

ISBN: 978-1-351-05166-8 (ebk)

Typeset in Sabon

by Apex CoVantage, LLC 


\section{Contents}

Acknowledgements viii

Notes on Contributors $\quad$ ix

Introduction: In Search for the Specific Unfolding of Authority and Power

NICOLAS BENCHERKI, FRANÇOIS COOREN AND FRÉDÉRIK MATTE

1 The Authority of the "Broader Context": What's Not in the Interaction?

MARIAELENA BARTESAGHI, OREN LIVIO, AND FRÉDÉRIK MATTE

2 The Varieties of (More or Less) Formal Authority

ALENA L. VASILYEVA, JESSICA S. ROBLES, JEAN A. SALUDADEZ, CHRISTIAN SCHWÄGERL, AND THERESA CASTOR

3 How Institutional Authority and Routine Exertions of Power Can Be Mobilized, Negotiated, and Challenged HELLE KRYGER AGGERHOLM, BIRTE ASMUß, GENEVIÈVE BOIVIN, RICHARD BUTTNY, AND KLAUS KRIPPENDORFF

4 Bodies, Faces, Physical Spaces and the Materializations of Authority

NICOLAS BENCHERKI, ALARIC BOURGOIN, HUEY-RONG CHEN, FRANÇOIS COOREN, VINCENT DENAULT AND

PIERRICH PLUSQUELLEC

5 God, Love, and the Apparently Immaterial Sources of Authority BERTRAND FAURÉ, THOMAS MARTINE, TRUDY MILBURN, AND KATHERINE R. PETERS 
vi Contents

6 Decentering the Analysis: The Authority of Spectators, Journalists and Others

CHANTAL BENOIT-BARNÉ, SKY MARSEN, NAN WANG,

AND YUE YANG

Appendix: Transcript of County Clerk Defying Supreme Court on Gay Marriage

Index 
To Jim and Elizabeth. You built an invulnerable fortress. 


\section{Acknowledgements}

The philosophers Gilles Deleuze and Félix Guattari begin their A Thousand Plateaus by discussing the process of writing their previous book, Anti-Oedipus, together. They note (in Brian Massumi's translation): "Since each of us was several, there was already quite a crowd." If coauthorship between two people is a crowd, then how can we qualify the present book, which involved twenty-seven different people, and anywhere between three and six authors per chapter? A swarm? A hive? It was, certainly, an adventure. Viewpoints and analytical traditions rubbed against each other and generated the heat that powered the writing process. The conviction that we were contributing to a unique project-looking at authority and power from interactional perspectives-shepherded a diverse group of academics through the loopholes of collaboration until we were able, together, to produce the distinctive piece of scholarship you hold in your hands (or read on your screen). We therefore address our first thanks to the authors who have contributed to this collection of chapters.

Besides the authors, many people made it possible for this project to come to fruition. We can't possibly name everyone, but you know who you are. However, we would like to specifically express our gratitude to Lise Higham, who made the first transcription of the video data that we analyze in this book. 


\section{Contributors}

Helle Kryger Aggerholm is head of research at the Danish School of Media and Journalism. Her research examines the role of communicative practices in strategic processes in public and private organizations, communication within a strategy-as-practice context, organizational communication (CCO) and language as social interaction.

Birte Asmuß is an associate professor at the Department of Management at Aarhus University, Denmark. Her main research interest is in the communicative and interactional foundations of management, leadership and organizations. She has published in leading international journals such as Discourse Studies and Journal of Communication Management.

Mariaelena Bartesaghi is an associate professor of communication at the University of Southern Florida. She studies institutionalization as dynamic between authority and accountability and by way of a synthetic and reflexive approach to discourse analysis.

Chantal Benoit-Barné is an associate professor in the Department of Communication at the Université de Montréal in Canada. Her research draws on rhetorical theories and communication as constitutive of organization (CCO) perspectives to explore the constitutive dimensions of communication in work interactions, public deliberations and sociotechnical controversies.

Geneviève Boivin is an assistant professor at the Université de Sherbrooke, Canada. Her research interests include the communicative constitution of organizations, institutional theory, intercultural communication and expatriation. Her work on the establishment of CCO scholarship has recently been published in Management Communication Quarterly.

Alaric Bourgoin is an assistant professor in the Department of Management at HEC Montréal, Canada. His research focuses on management consulting, value and power. Specifically, he studies the valuation 
practices of business consultants through a pragmatist lens. His coauthored Capitalization: A Cultural Guide is an anthropological investigation of the culture of contemporary capitalism.

Richard Buttny is professor of communication and rhetorical studies at Syracuse University, New York. His areas of interest include social accounting, metadiscourse and environmental discourse such as controversy on hydrofracking, animal rights or climate change.

Theresa Castor is a professor of communication at the University of Wisconsin-Parkside. Her research is in the general areas of organizational communication, and language and social interaction. Her current research involves the analysis of how risk and organizational crises are discursively constructed and the intersections of discourse, materiality and agency, with specific attention to projecting/ anticipating future risks.

Huey-Rong Chen is an associate professor in the Department of Journalism, Chinese Culture University, Taiwan. As a trained researcher in Greimasian semio-narrative theory, she has applied Greimas's concepts in exploring global/local interaction/construction of identity and the relationship between technologies and human reflexivity.

Vincent Denault is a $\mathrm{PhD}$ candidate and lecturer at the Department of Communication of the Université de Montréal. He is the co-founder and co-director of the Center for Studies in Nonverbal Communication Sciences of the Research Center of the Montreal Mental Health University Institute.

Bertrand Fauré is an associate professor of organizational communication at the University of Toulouse. His research on the performativity of the language of numbers in organizations is published in major journals of communication and management.

Klaus Krippendorff, professor of communication at the University of Pennsylvania, addresses theories of communication, cybernetics, content analysis and design. He writes of discursive constructions of scientific, social, technological and material realities and possibilities of emancipation from burdensome social or political constructions.

Oren Livio is a lecturer at the Department of Communication, University of Haifa. His research focuses on discursive and cultural negotiations of national identity, militarism, civic participation and protest, particularly in the Israeli context.

Sky Marsen is an associate professor at Flinders University, South Australia. As a linguist and communication specialist, her interests include discourse analysis of professional writing, organizational communication and crisis communication. She has lectured at universities 
internationally, including at California Institute of Technology, Victoria University of Wellington and University of Southern California.

Thomas Martine is an assistant professor at Audencia Business School in Nantes, France. His research focuses on the processes of group creativity and collaborative technology in organizations. His work has been published, among others, in Management Communication Quarterly and the Journal of Creative Behavior.

Trudy Milburn is assistant dean of liberal arts \& sciences at Purchase College, SUNY. She is co-editor of Engaging and Transforming Global Communication Through Cultural Discourse Analysis (2019) and editor of Communicating User Experience (2015). Her work examines discursive ways membership categories are enacted and displayed in organizational settings, both online and face-to-face.

Katherine R. Peters completed her PhD in communication at the University of Colorado-Boulder. Her research uses ethnography to investigate organizational meetings as emergent events that produce the effects of organization and culture. She is also interested in how technologies participate in communication events, like meetings, and the appearances of order and disorder in organizing.

Pierrich Plusquellec is an ethologist and associate professor in the School of Psychoeducation at the Université de Montréal, where he co-directs the Centre for Studies on Human Stress. He also co-directs the Center for Studies in Nonverbal Communication Sciences of the Research Center of the Montreal Mental Health University Institute. His publications discuss nonverbal sensitivity in relation to burnout and stress.

Jessica S. Robles is a member of the Discourse and Rhetoric Group (DARG) at Loughborough University. Her research uses discourse and conversation analysis to examine the social organization of difference and its relevance to how people interactionally manage ordinary moral troubles in their everyday lives.

Jean A. Saludadez is a professor and faculty administrator at the University of the Philippines Open University, where she also teaches communication theory and research and organizational communication at the graduate level. Her research interest is in understanding virtual organizations.

Christian Schwägerl is professor of communication management at Hochschule Osnabrück, University of Applied Sciences, Germany. He specializes in organizational communication and linguistic varieties in workplace communication.

Alena L. Vasilyeva is an assistant professor of communication at University of Massachusetts Amherst. Her general research interests include 


\section{xii Contributors}

deliberation, disagreement management, social identity, communication design and the coordination of actions in personal and public contexts.

Nan Wang is an associate professor at the School of Public Administration, Hunan University. Nan completed her PhD in sociology at University of California, Los Angeles. Her research focuses on talk and social institutions. She is actively collaborating in the context of several disciplines such as communication, medicine and artificial intelligence.

Yue Yang is a $\mathrm{PhD}$ candidate at the University of Southern California, where she studies media and social change in China by examining how medical institutions are changing as Chinese medical professionals actively participate in online communication during China's tensionridden healthcare reform. Her research concerns new media, controversies, contentious politics and governance of medicine in China. 


\title{
Introduction
}

\section{In Search for the Specific Unfolding of Authority and Power}

\author{
Nicolas Bencherki, François Cooren, \\ and Frédérik Matte
}

This book takes as a starting point a polemical assertion: that current literature on authority and power does not, in fact, specifically observe authority or power. This is not to say that the literature is wrong. Existing perspectives are quite correct when they provide insight on the way income, gender or racial differences are perpetuated (e.g., Ashcraft \& Mumby, 2004; Lee Ashcraft \& Allen, 2003) or how our views of management are rooted in war (Banerjee, 2008). These studies have drawn attention to the fact that the current state of relations between groups of people is anything but "normal," as in fact a lot of political work is involved in making them appear natural to begin with and to maintain their matter-of-fact character (Deetz, 1992).

In this sense, studies of power and authority-and related conceptshave drawn attention to the way cultural industries may obfuscate individual agency and reason (Gramsci, 1971; Horkheimer \& Adorno, 2002; Kracauer, 1930, 1998), to the way documents, records, and archives are forms of population control (About \& Denis, 2010; Derrida, 1996; Vismann, 2008), or to how bodies are turned into citizens through inclusion in the political body (Agamben, 1998). Authors from a range of disciplines have shown that authority and power are diffuse and shift shape to espouse the contours of the many instruments and apparatuses through which people's behavior is directed and corrected (Foucault, 1977/1995). So far, scholarship has therefore offered us a political perspective to our social life. To them, authority and power are vantage points from which to study society, but the notions have been deemed both too polymorphous and too fleeting to be pinned down. It has always appeared that any one definition would blind us to other centers of power and leave us vulnerable to ceaselessly renewed arrangements of control and exploitation.

Those authors who did venture definitions of power and authority have often done so by contrasting them from each other or from other neighboring notions. The first to do so was arguably Weber (1922/1968, p. 941), for whom "domination" is the "quite general" term that designates "the possibility of imposing one's own will upon the behavior of other persons," which can take the form of economic power whereby 


\section{Nicolas Bencherki, François Cooren, et al.}

someone commands resources that correspond to the recipient's interests, while authority would consist in the "power to command and duty to obey" derived from tradition, charisma or the law. For Simon (1947/1997, p. 180), authority rests in the suspension of choice between alternatives, thus leaving the decision to the superior, whereas influence is the assessment of arguments provided and deliberate choice between options.

In contrast, Lukes (1974/1998, p. 23) views authority as the subordinate's agreement with the content of a decision or with the process through which it is reached (and it is a form of power only if it is not, in fact, consensual), thus covering both authority and influence in Simon's (1947/1997) definition. Lukes (1974/1998, p. 31) also compares his perspective to Parsons' (1967, p. 308) view of power as a "capacity to secure the performance of binding obligations by units in a system of collective organization," which arguably covers what others would view as authority. Galbraith (1983), for his part, distinguishes between condign power (or coercion), compensatory power (based on rewards) and conditioned power (based on persuasion), which take their source either from an individual's personality, property of resources or organizational hierarchy. These many contrasting, if not opposing, definitions point to the fact that power, authority and their related notions are elusive and that there is a need to change perspectives on how we approach them.

We have given just this task to the authors who contribute to this book: we asked them to share with us their perspective on how to tangibly observe and analyze authority and power. To make sure that we were all talking about the same empirical phenomenon, we added a further constraint by asking all authors to analyze the same interaction between Kim Davis, the former county clerk of Rowan County, Kentucky, and David Moore and David Ermold, a couple seeking a marriage license after the 2015 decision by the Supreme Court of the United States to strike down all bans of same-sex unions. Despite several attempts-which the couple recorded, and to which they often invited supporters and members of the press-Davis continuously refused to provide them with a marriage license, invoking her faith as a justification for her defiance of the Supreme Court ruling. It is only after Davis was incarcerated for contempt of court that, eventually, the couple was able to obtain a license.

The particular event which we asked contributors to this book to analyze took place in 2016. The excerpt, which is available on USA Today's YouTube channel as well as on David Ermold's, was largely disseminated through the media and is exceptionally rich. In particular, it involves several participants besides Davis and the couple. Moore and Ermold have several supporters and members of the press on their side (including another couple who eventually joins them in requesting a marriage license). On the other side of the counter, two other clerks remain mostly silent, while Flavis McKinney, a retiree who offers Davis moral support, is more vocal in encouraging her. As the chapters will all point out, the 
interactional scene is therefore much more sophisticated than usual superior-subordinate models suggest, and authority is all the more fascinating to analyze. The issue at stake-gay marriage-being a hotly debated human rights problem also makes it even more challenging to remain at the level of the interaction and resist the temptation to recourse to moral or psychological explanations, for instance. Despite this added complexity, all of the chapter contributors show that it is, indeed, possible to point at the way authority and power are concretely achieved in interaction.

In the following section, we present the dominant view to authority and power, which we propose to refer to as a "possessive" understanding (following Tello-Rozas, Pozzebon \& Mailhot, 2015). After that, we introduce a distinction between power-over, power-to and power-with (which we borrow from Follett, 1940) that helps tease out the benefits of moving past a focus on authority and power as something people possess. We then show that some precursor work has already hinted at the value of an interactional perspective before suggesting that empirical studies are already being conducted that take the interactional dimensions of authority and power seriously. This introduction ends by presenting the different chapters of this book.

\section{The Possessive Epistemology of Power}

While attempts to define authority and power have been divergent, we can observe at least some broad tendencies in the literature. Many have described power and authority following a "possessive epistemology" (Tello-Rozas et al., 2015). Indeed, authors have been conceptualizing authority and power as something people may "have," or as the outcome of having something. Hobbes (1651/1987, Chapter X) already defined power in possessive terms: "The power of a man, to take it universally, is his present means to obtain some future apparent good." More recently, Barnes (1984, p. 180) distinguished the relation between authority and power using a possessive vocabulary: "to possess authority is to possess less than to possess power." The relationship between power and possession, indeed, is solidly anchored in Western thinking (Field, 1941; Nichols, 2017), making the owning of resources a key leverage for the exercise of power. Inheriting, among others, from Locke (1689/1821; see also Keyes, 1981 on Marx), we continue to believe power derives from property (of labor, of capital, etc.), and ultimately from one's ownership of one's own self, granted by none other than God.

Among these resources, the most commonly discussed is one's hierarchical position. "Holding" a position means having "the authority to give the commands required for the discharge of these duties" (Weber, $1922 / 1968$, p. 956). Giddens (1984, p. 258) proposes that authoritative resources derive "from the capability of harnessing the activities of human beings." Haugaard (1997, p. 111) further explains that "the actors 


\section{Nicolas Bencherki, François Cooren, et al.}

who possess authoritative resources are those who can influence the life chances of others and/or patterns of structural reproduction." Holding that position may be achieved through bureaucratic rules but also through economic and legal tools; indeed, as Aghion and Tirole (1997, p. 2) explain, the "right to decide" is allocated through an "explicit or implicit contract," especially when it comes to shareholders' power. Power also derives from the possession of natural and technological resources. For instance, Mitchell (2013) describes how energy-production technology, in particular the switch from coal transportation by ship to oil transportation through pipelines, changes relationships of power by taking away resources from workers, including the ability to obstruct transportation activities.

Other resources whose possession grants authority and power are French and Raven's (1959) five "bases" of power-reward, coercion, legitimacy, reference and expertise. For French and Raven, these operate principally at a psychological level. For instance, reference provides a person with power over another person because the latter is attracted to or identifies with the former. Similarly, French and Raven conceive of expertise as the perception the recipient has of the emitter's knowledge. Social psychology has also suggested that the possession of specific skills or personality traits contributes to leadership and authority, such as different forms of intelligence in leaders (Boyatzis, Good, \& Massa, 2012) or neuroticism in followers (Hetland, Sandal, \& Johnsen, 2008). Each time, there is a supposition that a person-either the emitter or recipient of authority and power-may either have those sources or personality traits, or acquire them, for instance through training.

Speaking of power and authority in possessive terms can be problematic for many reasons, not the least of which being that it displaces the problem from the proprietor to the things possessed: saying that someone is powerful because they possess a resource raises the question of how that resource "has" power in its turn. For instance, how legitimacy may be "had" and how it affords authority is itself a conundrum (e.g. Ashforth \& Gibbs, 1990; Erkama \& Vaara, 2010). Expertise also constitutes a field of study in its own right (see Eyal, 2013). As for personality traits, the way they translate into concrete (inter)action remains problematic (see van Vuuren \& Cooren, 2010).

\section{From Having "Power-Over" to Doing “Power-With"}

Instead of looking at power and authority from the perspective of the resources that would enable them, they can also be studied from the vantage point of their "uses," a perspective to which Simon (1947/1997, p. 186) hinted. For him, authority (and power, arguably) "enforces responsibility" (by allowing the imposition of sanctions on disobeying subordinates), "secures expertise in the making of decisions" (by restricting decisions to 
those authorized to make them) and "permits coordination of activities" (by ensuring that all subordinates follow the same general plan). These three "uses" can usefully be reworded using Follett's (1940, p. 78) distinction between power-over, power-to and power-with.

A lot of ink has been expended on the power-over perspective, which attempts to understand how an elite group of people can control others or a set of resources. This corresponds, for instance, to Dahl's (1957, p. 202) widely accepted definition: "A has power over B to the extent that he can get B to do something that B would not otherwise do." Besides the emphasis on the possession of resources discussed above, power-over is also the view adopted by many discourse-based discussions of power. For instance, Lukes (1974/1998) notes that besides the traditional focus on decision-making, studying power also requires looking at non-decisionmaking power, which concerns topics that are kept outside of the realm of debate, as well as at ideological power, which reveals itself in the discrepancy between real and expressed interests.

Some of Lukes' ideas can, coarsely, be seen to align with Foucault's (1977/1995), although Lukes distinguishes himself from his predecessor. In particular, Foucault views power as consisting in discursive and embodied "regimes of truths." These make power a relationship not between the powerful and the powerless but between all individuals and a constitutive feature of subjects. Authority, for its part, would consist in power relations' preoccupation with establishing their own truth, as in the case of experts such as physicians. Gramsci (1971) offers a similar view of power as stemming from hegemonic discourse: whoever can change power relations and make them appear commonsensical gains power-but being able to resist those discursive formations is power too. More recently, and with a more attentive focus on specific strategies by which hegemonic discourse is made possible, Clegg, Courpasson, and Phillips (2006, p. 2) have suggested that power follows specific "circuits," such as the episodic circuit of interactions, which in turn constitutes a dispositional circuit of meanings that form rules to be mobilized in further episodes, and a facilitative circuit that corresponds to the technologies that are put in place and that constrain or enable further episodes. Deetz $(1982,1992)$, for his part, stresses the importance of communication both in enabling and in revealing the naturalization of power relations, especially through specific conversational moves serving to obscure alternatives.

Building on these ideas, but shifting the emphasis to the ability of agents to act despite established systems of relations, some authors have adopted a "power-to" perspective and suggested that power should be understood as "the probability that one actor within a social relationship will be in a position to carry out his [sic] own will despite resistance" (Weber, $1922 / 1968$, p. 53). For Giddens (1984, p. 14), this ability to act even in the face of adversity is a fundamental component of agency: "an agent ceases to be such if he or she loses the capability to 'make a difference,' 
that is, to exercise some sort of power." It is also at the heart of Crozier and Friedberg's (1980) understanding of power as the margin of freedom a person retains in negotiating or resisting against the system of relations where they act. Such a view undergirds new institutional perspectives, in particular the literature on "institutional work" that proposes that people can alter the structures that constrain them (Lawrence \& Suddaby, 2006; Zundel, Holt, \& Cornelissen, 2013).

Rather than opposing a top-down or bottom-up view of power and prioritizing either component of the "duality of structure" (Giddens, 1984, p. 15), some authors have privileged a more immanent perspective. Adopting a "power-with" approach, they have insisted on the fact that power never leaves the firm ground of relations between individuals. Hegemonic discourse, for instance, may exist, but it exists not above but between individuals. At once refuting a possessive epistemology of power and a "power-over" perspective, Arendt (1972/2001, p. 44) explains that:

Power corresponds to the human ability not just to act but to act in concert. Power is never the property of an individual; it belongs to a group and remains in existence only so long as the group keeps together. When we say of somebody that he is "in power" we actually refer to his [sic] being empowered by a certain number of people to act in their name.

A power-with perspective, and its contrast with a possessive epistemology, is also summarized in Latour's (1986, p. 264) suggestion that power is always mediated by others: "when you simply have powerin potentia-nothing happens and you are powerless; when you exert power-in actu—others are performing the action and not you."

\section{A Situational View of Authority}

The best formulation of the power-with perspective comes from Follett (1940), who promulgated the "law of the situation," meaning that one person does not give orders to another but rather that both agree to defer to what the situation dictates. This casts the work of the researcher, but also the manager's, in a new light:

Our job is not how to get people to obey orders, but how to devise methods by which we can best discover the order integral to a particular situation. When that is found, the employee can issue it to the employer, as well as employer to employee.

(Follett, 1940, p. 35)

For Follett (1940, p. 83), the law of the situation has normative and emancipatory force: "If both sides obey the law of the situation, no person 
has power over another." Rather, people alter their relationships within each situation as they respond to it, thus continuously shaping new situations that "demand" new comportment from them. Follett calls for superiors and subordinates to come to a common understanding of the situation where they find themselves and to act together according to the situation's contingencies, rather than to confront each other. However, the law of the situation can also be understood as an empirical state of facts: it is the case, indeed, that people respond to continuously emerging situations, even when that situation consists in their superior giving them direct orders. The role of the researcher is to document how participants to a situation jointly figure out what it demands, how to react to it and possibly how to shape it in their turn (Bencherki \& Bourgoin, in press).

A power-with perspective thus invites looking at authority and power as a situational accomplishment. This contrasts with the tendency to deductively and a priori define authority and power or to conflate having a clear understanding of these phenomena and reducing them to a few characteristics. A situational view, on the contrary, embraces the multifaceted, ephemeral and pervasive nature of authority, and yet paves the way to a detailed description of its inner workings. Following that path, we could hope to make power and authority accessible, at once to be researched, to be exercised and to be resisted.

Some authors have laid groundwork for a situational view of power and authority. They stress the role of communication and situate authority and power in the realm of interaction, at least in broad strokes. For instance, for Chester Barnard (1938/1968, p. 163):

Authority is the character of a communication (order) in a formal organization by virtue of which it is accepted by a contributor to or a "member" of the organization as governing the action he contributes; that is as governing or determining what he does or is not to do so far as the organization is concerned.

While it may be read as an invitation to study what "character" in a communication makes it authoritative, thus putting the emphasis on the "message," Barnard's suggestion can also be read, in a more generous manner, as leaving room for the "recipient" of authority to choose or not to be guided by that message, thus offering elements of an interactional approach (for a comparison of studies of "message" and studies of interaction, see Pomerantz, Sanders, \& Bencherki, 2018).

Herbert Simon (1947/1997, p. 178) also hints at the interactional nature of authority when he explains that "each of the coordinated individuals sets for himself a criterion of choice that makes his [sic] own behavior dependent upon the behavior of others" and that "he makes his own decision at each point as to what those adjustments should be." For Simon, authority is a "relationship" between two individuals where 


\section{Nicolas Bencherki, François Cooren, et al.}

a superior "frames and transmits decisions with the expectation that they will be accepted by the subordinate," and where the subordinate "expects such decisions" and accepts to adjust his or her conduct to them (p. 179). While Simon can hardly be considered an analyst of interactions, he had the merit of recognizing that authority does not reside (only) in an individual's resources or skills but (also) in the relationship between people, in the expectations they hold towards each other and in the way they adjust their respective conduct according to those expectations.

However, a truly situational view of authority, living up to the program laid out by Follett and integrating the insights Barnard and Simon point out - that people orient to each other's (communicative) actionsis just beginning to be formulated. This is particularly true in the efforts of interaction scholars.

\section{Studying Power and Authority in Interaction}

Looking at authority and power from an interactional standpoint has often been deemed impossible. In particular, studies on language and social interaction have often been criticized for their alleged incapacity to deal with questions of power, coercion and domination (Cooren, 2007). By exclusively focusing on what people do in interactional scenes, these studies have indeed been accused of being ill-equipped to address and analyze what makes the interactions they study possible in the first place (Reed, 2010). They overlook, the argument goes, the key role that structures, ideologies and power relationships play in the constitution of interactions. However, it remains unclear how these structures, ideologies and power relationships concretely manifest themselves in interaction. For the past twenty years, a growing movement of scholars has decided to go beyond the sterile opposition between agency and structure by openly analyzing everything that happens to make a difference in a given interaction (Bartesaghi, 2009, 2014; Bencherki \& Cooren, 2011; Benoit-Barné \& Cooren, 2009; Castor \& Cooren, 2006; Chiang, 2015; Cooren \& Matte, 2010; Taylor \& Van Every, 2011, 2014). Instead of exclusively focusing on what people do, these scholars have also considered other forms of agency or authorship that seem to make a difference through people's turns of talk.

Critical discourse analysis is probably the approach that most explicitly formulates the agenda of studying power through its manifestations in communication and interaction (Fairclough \& Wodak, 1997). While it also recognizes that domination is jointly produced by the dominated, who may naturalize the uneven properties of the relationship, CDA is, however, often biased towards the study of how elites discursively reproduce their dominant position: "CDA should deal primarily with the discourse dimensions of power abuse and the injustice and inequality that result from it" (van Dijk, 1993, p. 252). CDA, in that sense, adopts a 
realist social ontology (Bartesaghi \& Pantelides, 2018) and borrows from Marx and the Frankfurt School in an attempt to integrate the structural conditions that affect discourse and language, and the constitutive role of language in reproducing structures (van Dijk, 1993). For instance, CDA research will explore the implications of news reports using the passive voice in creating ambiguity over the source of agency (Blommaert \& Bulcaen, 2000).

CDA's attempt to combine the minutiae of language with the broader context of its use has therefore brought criticism from both sides. As Bartesaghi and Pantelides (2018) point out, CDA has been accused both of adopting too narrow a perspective, thus blinding itself to the social and structural aspects of power, and, on the other side, of bringing ideological a priori into its analysis of discourse. In that sense, CDA is exemplar of the very dilemma confronting interaction scholars in the study of power and authority, as to whether these can be found within interaction or are to be observed outside of it.

Strictly interaction-based approaches to authority and power, which would bracket out from the analysis everything that takes place outside from the situation at hand, remain rare. Many studies have touched upon situations where relations could arguably be described as asymmetrical. This is the case of Sanders' (1995) study of the strategic enactment of superior and subordinate role-identities. Zemel and Koschmann's (2016) work on instruction during surgical training, or Davies' (1990) analysis of agency allocation in the classroom, similarly describe how, through interaction, some people are jointly constituted as authoritative and others less so. These studies, following one version or another of conversation analysis, build on the idea that authority or power do not lie in the hands of one person or another but in their interactions. This idea is strikingly obvious when looking for occurrences of the word "power" in Sacks' (1992) Lectures on Conversation. With few exceptions, Sacks attributes power not to people but to procedures, devices and methods that people employ as part of their interactions. The only moment when Sacks may appear to agree with the "power-over" perspective is when he attributes power to culture in his famous lecture "The baby cried. The mommy picked it up" (Sacks, 1992, p. 236). Even then, though, Sacks proceeds to discuss membership categorization devices and situates culture not in some looming, disincarnate force, but rather in people's conversational practice.

Following the idea that power pertains to interactional practices rather than to people, some rare explicit discussions of authority exist in communication studies. This is the case, for instance, of Benoit-Barné and Cooren's (2009) proposal that authority is the outcome of practices by which people invoke various figures with which they share their actions (see also Benoit-Barné \& Fox, 2017). Similarly, Taylor and Van Every (2014) have shown that organizational members discursively constitute 


\section{0}

Nicolas Bencherki, François Cooren, et al.

their organization as a "third" to which they agree to defer. These studies explicitly or implicitly build on Follett's (1940) view that people take their orders from the situation rather than from each other. For instance, Sanders and Bonito (2010) have shown how invoking the interest of the court proceeding or that of the judicial system in general is a way for a juror to exert influence on their peers. This sharing of the action's authorship between the juror and the institution in which they are involved thus multiplies the number of "authorities" that dictate the suggested course of action and that therefore lend it their authority.

The relationship between authority and authorship is also at play in Bartesaghi's (2009) suggestion that psychotherapist's authority proceeds from their ability to substitute patients' accounts with a therapeutic version. In agreement with this idea, other studies have shown how, in conversation, various matters of concern can come to be recognized as "co-authoring" or demanding particular courses of action, thus becoming "matters of authority." In other words, the distinction between elements that are "authoritative" and those that are not cannot be established ahead of the interactional situation where they are made relevant (BenoitBarné \& Cooren, 2009; Vásquez, Bencherki, Cooren, \& Sergi, 2018).

\section{Six Issues Concerning the Interactional Study of Authority and Power}

To lay out a program for the study of authority and power from an interactional standpoint, we asked several authors-some of them wellestablished in the discipline, others up-and-coming-to look at the interaction between Kim Davis, David Moore and David Ermold. We asked each group of authors to ask a different question to the interaction, meaning that they had to tease out a different facet of what is going on in that county clerk's office. The analysis of a same interaction means that chapters refer to the same events, people and things. This may appear as redundant. However, as the reader will note, each approach and each chapter's focus connect those elements differently, bringing to light different relations between them. Within each chapter, we asked the different authors not to iron out their analytical differences but rather to make them apparent and to explain the merits and limitations of each interactional approach in teasing out the phenomenon being considered. Contributors, then, were honest and upfront about their different assumptions, and each guides the reader through what his or her perspective may or may not achieve to observe authority and power as they unfold in the interaction.

Chapter 1, titled "The Authority of the 'Broader Context': What's Not in the Interaction?" looks at authority by highlighting how any text is always both a product and a producer of its very context. Bartesaghi, Livio and Matte show from this "wide-angle" perspective that rapports of authority taking place locally also bring to the table broader issues 
situated within the larger history of intolerance and discrimination. More specifically, these authors mobilize three complementary lenses to analyse the first twenty-five lines of the interaction where a "smile" from Kim Davis brings into being a more complex storyline than what it looks like at first. Conversation analysis (CA), the notion of dislocation and critical discourse studies (CDS) are mobilized to illustrate how this apparently inoffensive smile produced by Davis makes contextually present saidto-be absentees (ideologies, past experiences, historical power structures, etc.) from other contexts. As shown in this chapter, this smile thus plays a constitutive role in the revelation of local games of authority.

While Bartesaghi, Livio and Matte demonstrate how the notion of context is first and foremost a question of definition and appropriation by actors in situations, chapter 2 addresses institutionalized and socially sanctioned forms of authority, that is, what can be considered varieties of (more or less) formal authority. Vasilyeva, Robles, Saludadez, Schwägerl and Castor show how this apparent fixed and reified authority (i.e., formal) appears, in fact, as an array of ongoing negotiations among actors throughout the interaction. These authors mobilize discourse analysis, conversation analysis and a ventriloquial approach to study authority and power as interactional accomplishment and matters of negotiation for participants in talk-in-interaction. For all of the approaches mobilized in this chapter, authority is therefore grounded in participants' actions, even if it is considered formal to begin with. Chapter 3, titled "How institutional authority and routine exertions of power can be mobilized, negotiated and challenged," invites us to study the many ways routines, rules, policies and procedures-i.e., institutionalized practices-are constitutive vectors of social encounters. Aggerholm, Asmuß, Boivin, Buttny and Krippendorff present several complementary viewpoints by which the emergence, enactment and demise of authority and power routines are analyzed. By looking at the data from a ventriloquial, accountability, micro-level as well as a multimodal routine perspective, each author of this chapter mobilizes their preferred approach to analyse the interaction. Boivin analyzes the many ways organizational actors ventriloquize and are ventriloquized by routines and procedures; Buttny discusses the role of the notion of accountability in constituting authority; Krippendorff also builds on the notion of accountability to show the critical role it plays in disrupting routine exertions of power; finally, Aggerholm and Asmuß stress the merits of multimodal analysis to look at how routines are mobilized or deviated from in constituting authority.

In chapter 4, titled "Bodies, Faces, Physical Spaces and the Materializations of Authority," we broaden the perspective about authority and power by decentering the analytical foci from human subjects. The authors of this chapter thus propose three complementary analytical positions that show how things-whether physical objects or seemingly abstract entities-fully participate in everyday interactions. Denault and 


\section{Nicolas Bencherki, François Cooren, et al.}

Plusquellec take insights from experimental research by comparing facial expressions to verbal statements and actions from their owner, an analysis that reveals discrepancies between the authority people invoke and what actually drives them to say what they say or do what they do. Bencherki and Bourgoin offer a transductive analysis by showing how things may participate in interaction regardless of the interpretation people make of them, as the meaning of their action proceeds for the contribution they make to broader activities. Finally, Cooren and Huey-Rong mobilize a ventriloquial perspective to show how the three people involved in the heated discussion can be positioned or position themselves as the channels by which other elements end up speaking and making a difference in the way the situation evolves.

In chapter 5, titled "God, Love and the Apparently Immaterial Sources of Authority," Fauré, Martine, Milburn and Peters envisage sources of authority that appear, at first sight, rather abstract and immaterial. These authors indeed focus their analysis on nothing other than love and God by showing how they can be brought into being through speech, tone and visible actions. To do so, they mobilize four complementary lenses to analyze how actors in the scene manage to evoke or invoke these sources of authority in their respective turns of talk. Martine uses a constitutive view of communication to show the very materialization of love and God in the interaction and the relative authority they acquire as a result. Peters presents an ethnography of communication perspective to stress the part cultural and historical understandings play a part in authority. Milburn, for her part, draws on cultural discourse analysis to show that cultural premises can be displayed or located in discursive practices and therefore that authority is manifested in the way people act and relate. Finally, Fauré looks at God and love as symmetrical authorities that can be more or less materialized, drawing attention to the notion of absence.

Last but not least, chapter 6, titled "Decentering the Analysis: The Authority of Spectators, Journalists and Others," offers yet another way to push the boundaries about authority by drawing attention to a broader range of people and objects in the scene, including those who do not speak. All four approaches mobilized in this chapter agree that authority is a dynamic and fluid phenomenon that is negotiated in social interactions even by agents that remain invisible. Benoit-Barné sees authority as being a relational occurrence happening through presentification. For Marsen, authority is mainly discursive and is manifested in the positioning of agents as well as the description of their actions and words by a narrator. For Yang, power and authority relate to widely shared assumptions by participants even if their manifestation depends largely on the situational constructions of relationships and identities. Finally, Wang mobilizes a conversation analytic approach to show how authority is socially constructed through participants' exchange of social actions. 


\section{Conclusion: Future Direction for Research}

Our hope with this book is twofold. On the one hand, we want to contribute to current conversations regarding authority and power, for instance in the fields of sociology or management, by showing that it is possible to specifically point to the interactional dynamics by which these phenomena materialize in each specific situation. This is important not only as an academic exercise to offer more analytical minutiae for the study of otherwise evanescent notions but also as a political project, as we strongly believe that providing concrete leverage for either exercising or resisting authority and power can only be done when we better understand their concrete, day-to-day unfolding. Indeed, as long as we speak of these notions in abstract terms, they will continue to appear unescapable, as if authority and power were already there, surrounding and trapping us. The fact may be, though, that we surround and trap each other in a joint accomplishment that we often more or less consciously deny afterwards.

On the other hand, we also want to make authority and power salient problems within the language and social interaction community. These notions have often appeared to be too loaded to researchers who have preferred to speak in terms of "directing," "instructing," "holding accountable" and so forth. The fact, though, is that these may correspond precisely to what other social scientists refer to as authority and power, although at a different level of detail. Interaction scholars are often reluctant to address "big issues" that may appear well beyond the scope of their studies of localized interactions. Yet, they also claim that there is nothing that is not local: this means that phenomena of authority and power can never be "beyond" their reach. It is therefore up to them, also, to provide their own contribution to questions that certainly concern the members they observe.

By stating that questions of authority and power are not their concerns, some interaction scholars may paradoxically reproduce two distinctions that they claim to reject, namely the micro vs. macro distinction (by thinking that these issues are beyond their scope) and the member vs. analyst distinction (by refusing to use members' terms). It is therefore about time to reappropriate those notions to show how they constitute interactional accomplishment and, in the process, make them less taboo for us as well as for those who must deal with them in their daily life.

\section{References}

About, I., \& Denis, V. (2010). Histoire de l'identification des personnes. Paris: La Découverte.

Agamben, G. (1998). Homo sacer: Sovereign power and bare life. Stanford, CA: Stanford University Press. 
Aghion, P., \& Tirole, J. (1997). Formal and real authority in organizations. Journal of Political Economy, 105(1), 1-29. https://doi.org/10.2307/2138869

Arendt, H. (2001). On violence (1st edition). New York, NY: Mariner Books. (Original work published 1972).

Ashcraft, K. L., \& Mumby, D. K. (2004). Reworking gender: A feminist communicology of organization. Thousand Oaks, CA: Sage. Retrieved from www.loc. gov/catdir/toc/ecip046/2003016116.html

Ashforth, B. E., \& Gibbs, B. W. (1990). The double-edge of organizational legitimation. Organization Science, 1(2), 177-194. https://doi.org/10.1287/ orsc.1.2.177

Banerjee, S. B. (2008). Necrocapitalism. Organization Studies, 29(12), 15411563. https://doi.org/10.1177/0170840607096386

Barnard, C. (1968). The functions of the executive. Cambridge: Harvard University Press. (Original work published 1938).

Barnes, B. (1984). On authority and its relationship to power. The Sociological Review, 32, 180-195. https://doi.org/10.1111/j.1467-954X.1984.tb00112.x

Bartesaghi, M. (2009). How the therapist does authority: Six strategies for substituting client accounts in the session. Communication \& Medicine, 6(1), 15-25.

Bartesaghi, M. (2014). Coordination: Examining weather as a "matter of concern”. Communication Studies, 65(5), 535-557. https://doi.org/10.1080/1051 0974.2014.957337

Bartesaghi, M., \& Pantelides, K. (2018). Why critique should not run out of steam: A proposal for the critical study of discourse. Review of Communication, 18(3), 158-177.

Bencherki, N., \& Bourgoin, A. (in press). “And who are you again?”: A performative perspective on authority in organizations. Academy of Management Journal.

Bencherki, N., \& Cooren, F. (2011). Having to be: The possessive constitution of organization. Human Relations, 64(12), 1579-1607. https://doi.org/10.1177/ 0018726711424227

Benoit-Barné, C., \& Cooren, F. (2009). The accomplishment of authority through presentification: How authority is distributed among and negotiated by organizational members. Management Communication Quarterly, 23(1), 5-31. https://doi.org/10.1177/0893318909335414

Benoit-Barné, C., \& Fox, S. (2017). Authority. In The international encyclopedia of organizational communication. Hoboken, NJ: John Wiley \& Sons, Inc. https://doi.org/10.1002/9781118955567.wbieoc011

Blommaert, J., \& Bulcaen, C. (2000). Critical discourse analysis. Annual Review of Anthropology, 29(1),447-466.https://doi.org/10.1146/annurev.anthro.29.1.447

Boyatzis, R. E., Good, D., \& Massa, R. (2012). Emotional, social, and cognitive intelligence and personality as predictors of sales leadership performance. Journal of Leadership \& Organizational Studies, 19(2), 191-201. https://doi. org/10.1177/1548051811435793

Castor, T., \& Cooren, F. (2006). Organizations as hybrid forms of life: The implications of the selection of agency in problem formulation. Management Communication Quarterly, 19(4), 570-600. https://doi.org/10.1177/0893318905284764

Chiang, S.-Y. (2015). Power and discourse. In K. Tracy, C. Ilie, \& T. Sandel (Eds.), The international encyclopedia of language and social interaction. Hoboken, NJ: John Wiley \& Sons, Inc. Retrieved from http://onlinelibrary.wiley.com/ doi/10.1002/9781118611463.wbielsi149/abstract 
Clegg, S. R., Courpasson, D., \& Phillips, N. (2006). Power and organizations. Thousand Oaks, CA: Sage.

Cooren, F. (Ed.). (2007). Interacting and organizing: Analyses of a management meeting. Mahwah, NJ: Lawrence Erlbaum Associates, Publishers.

Cooren, F., \& Matte, F. (2010). For a constitutive pragmatics: Obama, Médecins Sans Frontières and the measuring stick. Pragmatics and Society, 1(1), 9-31. https://doi.org/10.1075/ps.1.1.02coo

Crozier, M., \& Friedberg, E. (1980). Actors and systems: The politics of collective action. Chicago, IL: University of Chicago Press.

Dahl, R. A. (1957). The concept of power. Behavioral Science, 2(3), 201-215.

Davies, B. (1990). Agency as a form of discursive practice. A classroom scene observed. British Journal of Sociology of Education, 11(3), 341-361. https:// doi.org/10.2307/1392847

Deetz, S. A. (1982). Critical interpretive research in organizational communication. Western Journal of Communication, 46(2), 131-149.

Deetz, S. A. (1992). Democracy in an age of corporate colonization: Developments in communication and the politics of everyday life. Albany: State University of New York.

Derrida, J. (1996). Archive fever: A freudian impression. (E. Prenowitz, Trans.). Chicago: University of Chicago Press.

Erkama, N., \& Vaara, E. (2010). Struggles over legitimacy in global organizational restructuring: A rhetorical perspective on legitimation strategies and dynamics in a shutdown case. Organization Studies, 31(7), 813-839. https:// doi.org/10.1177/0170840609346924

Eyal, G. (2013). For a sociology of expertise: The social origins of the autism epidemic. American Journal of Sociology, 118(4), 863-907. https://doi.org/10. $1086 / 668448$

Fairclough, N., \& Wodak, R. (1997). Critical discourse analysis. In T. A. van Dijk (Ed.), Discourse as social interaction (pp. 258-284). Thousand Oaks, CA: Sage.

Field, O. P. (1941). Property and authority. The Journal of Politics, 3(3), 253-275. https://doi.org/10.2307/2125564

Follett, M. P. (1940). The dynamic administration: The collected papers of Mary Parker Follett. London: Routledge.

Foucault, M. (1995). Discipline and punish: The birth of the prison. New York: Vintage Books. (Original work published 1977).

French, J. R. P., \& Raven, B. (1959). The bases of social power. In D. Cartwright (Ed.), Studies in social power (pp. 150-167). Oxford: University of Michigan Press.

Galbraith, J. K. (1983). The anatomy of power. Boston, MA: Houghton Mifflin.

Giddens, A. (1984). The constitution of society: Outline of the theory of structuration. Cambridge, UK: Polity Press.

Gramsci, A. (1971). Selections from the prison notebooks. (Q. Hoare \& G. Nowell Smith, Trans.). New York, NY: International.

Haugaard, M. (1997). The constitution of power: A theoretical analysis of power, knowledge and structure. Manchester: Manchester University Press.

Hetland, H., Sandal, G. M., \& Johnsen, T. B. (2008). Followers' personality and leadership. Journal of Leadership \& Organizational Studies, 14(4), 322-331. https://doi.org/10.1177/1548051808315550

Hobbes, T. (1987). Leviathan. London: Dent. (Original work published 1651).

Horkheimer, M., \& Adorno, T. W. (2002). Dialectic of enlightenment. (G. Schmid Noerr, Ed., E. Jephcott, Trans.). Stanford, CA: Stanford University Press. 
Keyes, T. W. (1981). Karl marx on property (Ph.D.). Marquette University, Milwaukee, WI. Retrieved from http://search.proquest.com/docview/303183896/ abstract

Kracauer, S. (1998). The salaried masses: Duty and distraction in Weimar Germany. (Q. Hoare, Trans.). London: Verso. (Original work published 1930).

Latour, B. (1986). The powers of association. In J. Law (Ed.), Power, action and belief: A new sociology of knowledge? (pp. 264-280). London: Routledge.

Lawrence, T. B., \& Suddaby, R. (2006). Institution and institutional work. In S. R. Clegg, C. Hardy, T. B. Lawrence, \& W. R. Nord (Eds.), Sage handbook of organization studies (2nd edition, pp. 215-254). Thousand Oaks, CA: Sage.

Lee Ashcraft, K., \& Allen, B. J. (2003). The racial foundation of organizational communication. Communication Theory, 13(1), 5-38. https://doi.org/10.1111/ j.1468-2885.2003.tb00280.x

Locke, J. (1821). Two treatises of government. London: Whitmore Fenn, and C. Brown. (Original work published 1689).

Lukes, S. (1998). Power: A radical view (Reprint). Houndmills: Macmillan. (Original work published 1974).

Mitchell, T. (2013). Carbon democracy: Political power in the age of oil (2nd Revised edition). London: Verso.

Nichols, R. (2017). Theft is property! The recursive logic of dispossession. Political Theory. https://doi.org/10.1177/0090591717701709

Parsons, T. (1967). Sociological theory and modern society. New York: Free Press.

Pomerantz, A., Sanders, R. E., \& Bencherki, N. (2018). Communication as the study of social action: On the study of language and social interaction: An interview with Anita Pomerantz and Robert E. Sanders, by Nicolas Bencherki. Communiquer. Revue de Communication Sociale et Publique, 22, 103-118.

Reed, M. (2010). Is communication constitutive of organization? Management Communication Quarterly, 24(1), 151-157. https://doi.org/10.1177/089331890 9351583

Sacks, H. (1992). Lectures on conversation. (G. Jefferson, Ed.). Cambridge, MA: Blackwell.

Sanders, R. E. (1995). A neo-rhetorical perspective: The enactment of roleidentities as interactive and strategic. In S. J. Sigman (Ed.), The consequentiality of communication (pp. 67-120). Hillsdale, NJ: Erlbaum.

Sanders, R. E., \& Bonito, J. A. (2010). Speaking for the institution: A fourth production site for group members' influence attempts. Small Group Research, 41(4), 427-451. https://doi.org/10.1177/1046496410366309

Simon, H. A. (1997). Administrative behavior: A study of decision-making processes in administrative organizations (4th edition). New York: Free Press. (Original work published 1947).

Taylor, J. R., \& Van Every, E. J. (2011). The situated organization: Studies in the pragmatics of communication research. New York, NY: Routledge.

Taylor, J. R., \& Van Every, E. J. (2014). When organization fails: Why authority matters. New York, NY: Routledge.

Tello-Rozas, S., Pozzebon, M., \& Mailhot, C. (2015). Uncovering micro-practices and pathways of engagement that scale up social-driven collaborations: A practice view of power: Micro-practices and pathways of engagement. Journal of Management Studies, n/a-n/a. https://doi.org/10.1111/joms.12148 
van Dijk, T. A. (1993). Principles of critical discourse analysis. Discourse \& Society, 4(2), 249-283. https://doi.org/10.1177/0957926593004002006

van Vuuren, M., \& Cooren, F. (2010). "My attitude made me do it”: Considering the agency of attitudes. Human Studies, 33(1), 85-101. https://doi.org/10.1007/ s10746-010-9137-x

Vásquez, C., Bencherki, N., Cooren, F., \& Sergi, V. (2018). From "matters of concern" to "matters of authority": Reflecting on the performativity of strategy in writing a strategic plan. Long-Range Planning, 51(3), 417-435. https://doi.org/10.1016/j. lrp.2017.01.001

Vismann, C. (2008). Files: Law and media technology. (G. Winthrop-Young, Trans.). Stanford, CA: Stanford University Press.

Weber, M. (1968). Economy and society: An outline of interpretive sociology. New York, NY: Bedminster Press. (Original work published 1922).

Zemel, A., \& Koschmann, T. (2016). A stitch in time: Instructing temporality in the operating room. Communication \& Medicine, 12(1), 85-98. https://doi. org/10.1558/cam.v12i1.25988

Zundel, M., Holt, R., \& Cornelissen, J. (2013). Institutional work in the wire an ethological investigation of flexibility in organizational adaptation. Journal of Management Inquiry, 22(1), 102-120. https://doi.org/10.1177/1056492612440045 
claims as analysts about the smile and how to be reflexive about them. This remains a problem for the other two analyses and, arguably, for $(\mathrm{C})$ DA more broadly. Whether attempting to construct and perfect a method for transcription and analysis in which the researcher is ideally (and idealized as) nonexistent, as in CA, or more explicitly acknowledging the analyst as part of the context and even considering this an inspired demonstration of the reflexive critical impetus, as in some Frankfurt School informed approaches to CDA (Reisigl \& Wodak, 2009; Wodak \& Meyer, 2009), both the theorizing and the systematic empirical operationalizing of the analyst's role as- and in-context remain underdeveloped.

It is here, perhaps, that incorporating more ethnographic tools associated with linguistic anthropology and the ethnography of communication may prove useful, a point indeed made by Blommaert (2005) and others. While some discourse analytic methods certainly employ such tools, their use is often pragmatic and limited.

To be sure, this is hardly a straightforward endeavor. In many cases, discourse analysts must grapple with discourses that are "already there," and this is not merely a matter of utility but also of necessity, given our role as watchers of already-present texts, events, and institutions. Some approaches to discourse analysis, such as Tracy's Action-Implicative Discourse Analysis (AIDA, e.g., 2010) that involves extensive fieldwork on everyday practices, or Wodak's DHA (e.g., Reisigl \& Wodak, 2009; Wodak, 2014), ordinarily incorporate ethnographic methods, but this sets some limits on what can be studied, how it can be studied, and what time frames are required-limitations that do not always fit researchers' agendas and possibilities.

Or, this might be an argument for what we have not included and may never know how to fully include, even as our fingers are typing this text to materialize the contexts of our analysis: our bodies and the bodies of others. Much like the service counter that both unites and divides the speakers on the scene and all the voices and the figures that are called to speak, present and absent, doing discourse analysis points to the limitations of capturing the sensory. Try as we may to meet the universe halfway (c.f. Barad, 2007) by inviting dislocation, ideologies, and technological displays into our analytical frames, the universe pushes us back. Though we may suspect what is and is not in an interaction, and though we may know it in our bodies, our discourse analyses have not yet provided us with adequate contexts to authorize this knowing.

\section{Notes}

1. The volleys spanned a three-year period (e.g., Schegloff, 1997; Billig, 1999), with a follow up by Kitzinger (2000). Not to be missed is Tracy's Forum (1998).

2. We employ DA as an umbrella term to several approaches to language and social interaction (see Stubbe et al., 2003; Tracy, 1998) that consider text and context to be politically and socioculturally entangled. 


\section{4}

Mariaelena Bartesaghi, Oren Livio, et al.

3. To avoid a strawman argument, we acknowledge that using images together with transcripts is not new. CA, for example, has been studying the gaze to understand how interaction is coordinated since its beginnings.

4. As the clip entreats, "watch Kentucky clerk" - thus setting up different in-themoment displays, each including different watchers.

\section{References}

Antaki, C., Billig, M., Edwards, D., \& Potter, J. (2003). Discourse analysis means doing analysis: A critique of six analytic shortcomings. Discourse Analysis Online, 1. Retrieved from www.shu.ac.uk/daol/articles/v1/n1/a1/antaki2002002-t.html

Barad, K. (2007). Meeting the universe halfway: Quantum physics and the entanglement of matter and meaning. Durham, NC: Duke University Press.

Bartesaghi, M. (2015). Intertextuality. In K. Tracy (Ed.), International encyclopedia of language and social interaction (pp. 901-906). New York: Wiley.

Benoit-Barné, C., \& Cooren, F. (2009). The accomplishment of authority through presentification: How authority is distributed among and negotiated by organizational members. Management Communication Quarterly, 23(1), 5-31.

Billig, M. (1999). Whose terms? Whose ordinariness? Rhetoric and ideology in conversation analysis. Discourse \& Society, 10(4), 543-558.

Blommaert, J. (2005). Discourse: A critical introduction. Cambridge, UK: Cambridge University Press.

Bucholz, M. (2000). The politics of transcription. Journal of Pragmatics, 32(10), 1439-1465.

Bucholz, M. (2007). Variation in transcription. Discourse Studies, 9(6), 784-808.

Buttny, R. (1993). Social accountability in communication. London: Sage.

Context. (2019). Merriam-webster dictionary. Retrieved from www.merriamwebster.com/dictionary/context

Cooren, F. (2010). Action and agency in dialogue: Passion, incarnation and ventriloquism. Amsterdam: John Benjamins.

Dunigan, J. S. (2018). Three years after Supreme Court ruling, at least 8 Alabama counties won't issue marriage licenses. AL.com. Retrieved from www.al.com/ news/birmingham/index.ssf/2018/06/three_years_after_supreme_cour.html

Fairclough, N. (1992). Discourse and social change. Cambridge, UK: Polity Press.

Fairhurst, G. T., \& Cooren, F. (2004). Organizational language in use: Interaction analysis, conversation analysis, and speech act schematics. In D. Grant, C. Hardy, C. Oswick, \& L. Putnam (Eds.), The Sage handbook of organizational discourse (pp. 131-152). London: Sage.

Fairhurst, G. T., \& Cooren, F. (2009). Leadership as the hybrid production of presence(s). Leadership, 5(4), 469-490.

Flowerdew, J. (2014). Introduction: Discourse in context. In J. Flowerdew (Ed.), Discourse in context (pp. 1-25). London: Bloomsbury.

Fox, B. A. (2012). Conversation analysis and self-repair. In C. Mortensen \& J. Wagner (Eds.), The encyclopedia of applied linguistics. Cambridge, MA: Wiley-Blackwell. https://doi.org/10.1002/9781405198431.wbeal0214

Garfinkel, J. (1967). Studies in ethnomethodology. New York: Prentice-Hall.

Goffman, E. (1983). The interaction order. American Sociological Review, 48(1), 1-17.

Grimshaw, A. D. (Ed.). (1990). Conflict talk: Sociolinguistic investigations of arguments in conversation. Cambridge, UK: Cambridge University Press. 
Hart, C. (2015). Viewpoint in linguistic discourse. Critical Discourse Studies, 12(3), 238-260.

Iedema, R. (2011). Discourse studies in the 21st century: A response to Mats Alvesson and Dan Kärreman's "Decolonializing discourse”. Human Relations, 64(9), 1163-1176.

Johnson,C.(2016,June22).Oneyearaftermarriageruling,pocketsofdefianceremain. Washington Blade. Retrieved from www.washingtonblade.com/2016/06/22/ one-year-after-supreme-court-ruling-pockets-of-marriage-inequality-remain/

Jones, R. H. (2009). Technology and sites of display. In C. Jewitt (Ed.), The Routledge handbook of multimodal analysis (pp. 114-126). London: Routledge.

Jones, R. H. (2016). Spoken discourse. London: Bloomsbury.

Kelly, A. (2015, September 26). Kim Davis' supporters, in their own words: "Courageous", "heroic". NPR. Retrieved from www.npr.org/sections/itsallpolitics/ 2015/09/26/443485200/courageous-heroic-meet-kim-daviss-supporters

Kitzinger, C. (2000). Doing feminist conversation analysis. Feminism \& Psychology, 10(2), 163-193.

Korobov, N. (2001). Reconciling theory with method: From conversation analysis and critical discourse analysis to positioning analysis. Forum: Qualitative Social Research, 2(3). Retrieved from www.utsc.utoronto.ca/ kmacd/IDSC10/ Readings/text \%20analysis/CDA.pdf

Kress, G., \& Van Leeuwen, T. (2001). Multimodal discourse: The modes and media of contemporary communication. London: Edward Arnold.

Kress, G., \& Van Leeuwen, T. (2006). Reading images: The grammar of visual design (2nd edition). London: Routledge.

Ochs, E. (1979). Transcription as theory. In E. Ochs \& B. Schieffelin (Eds.), Developmental pragmatics (pp. 43-72). New York: Academic Press.

Petitjean, C., \& González-Martínez, E. (2015). Laughing and smiling to manage trouble in French-language classroom interaction. Classroom Discourse, 6(2), 89-106.

Reisigl, M., \& Wodak, R. (2009). The discourse-historical approach (DHA). In R. Wodak \& M. Meyer (Eds.), Methods of critical discourse analysis (2nd edition, pp. 87-121). London: Sage.

Robles, J. S., \& Castor, T. (2017, May). Taking the moral high ground: Avoiding accounts as a practice for being uncompromisingly principled. Paper presented at the International Communication Association, San Diego, CA.

Schegloff, E. A. (1997). Whose text? Whose context? Discourse and Society, 8(2), 165-187.

Schegloff, E. A. (2000). On granularity. Annual Review of Sociology, 26, 715-720.

Scollon, R. (1998). Mediated discourse as social interaction: The study of news discourse. London: Longman.

Stubbe, M., Lane, C., Hilder, J., Vine, E., Vine, B., Marra, M., Holmes, J., \& Weatherall, A. (2003). Multiple discourse analyses of a workplace interaction. Discourse Studies, 5(3), 351-388.

Taylor, J. R., \& Van Every, E. J. (2000). The emergent organization: Communication as site and surface. Mahwah, NJ: Lawrence Erlbaum.

Tracy, K. (1998). Analyzing context: Framing the discussion. Research on Language and Social Interaction, 31(1), 1-28.

van Dijk, T. A. (1977). Text and context. London: Longman.

van Dijk, T. A. (2008). Discourse and power. New York: Palgrave Macmillan. 


\section{Mariaelena Bartesaghi, Oren Livio, et al.}

van Dijk, T. A. (2009). Critical discourse studies: A sociocognitive approach. In R. Wodak \& M. Meyer (Eds.), Methods of critical discourse analysis (2nd edition, pp. 62-86). London: Sage.

Vásquez, C., \& Cooren, F. (2013). Spacing practices: The communicative configuration of organizing through space-times. Communication Theory, 23(1), 25-47.

Watch Kentucky clerk defy Supreme Court on gay marriage. (2015, September 1). USA Today. Retrieved from www.usatoday.com/videos/news/nation/2015/ 09/03/71527640/

Wetherell, M. (1998). Positioning and interpretive repertoires: Conversation analysis and poststructuralism in dialogue. Discourse \& Society, 9(3), 387-412.

Wodak, R. (2011). The discourse of politics in action: Politics as usual (2nd edition). Basingstoke: Palgrave.

Wodak, R. (2014). Political discourse analysis: Distinguishing frontstage and backstage contexts: A discourse-historical approach. In J. Flowerdew (Ed.), Discourse in context (pp. 321-345). London: Bloomsbury.

Wodak, R., \& Meyer, M. (2009). Critical discourse analysis: History, agenda, theory and methodology. In R. Wodak \& M. Meyer (Eds.), Methods of critical discourse analysis (2nd edition, pp. 1-33). London: Sage.

Wooffitt, R. (2005). Conversation analysis and discourse analysis: A comparative and critical introduction. London: Sage. 
"God," federal law, etc.). With specific reference to formal authority in terms of institutional positioning, interlocutors disagreed on what figures should take precedence in how Davis's formal authority should be constituted, with Davis narrowly focusing on her "job" and Ermold and others addressing her responsibilities within the context of the recent court ruling.

In applying conversation analytic, discourse analytic, and ventriloquial approaches, we note that they are compatible in illustrating how varieties of formal authority are negotiated through language-use in social interactions. Where they differ is in the aspects of conversation that they attend to, with DA analyzing identities and discursive strategies, CA focusing on conversational sequence and how participants orient to institutional rules, and the ventriloquial approach examining how authority is accomplished in a topical and content-oriented way, focusing on direct and indirect references to sources of authority. DA and ventriloquial approaches noted how institutional language was used to navigate complying and not complying with local expectations, as well as the different ways legitimacy was enacted. On the other hand, DA and CA have more in common with each other in terms of examining interaction-CA in particular focuses on turn-by-turn actions-while ventriloquial analysis can examine a single utterance.

For all of the methods applied herein, "authority" is grounded in participants' actions: what they say and do. Even the extent to which authority is "formal" is negotiated and performed, reproduced and resisted, in the participants' local organization of their activities. These perspectives on more or less formal varieties of authority may emphasize different mechanisms for how authorities are made relevant (e.g., in the display of identities and framing of talk versus the sequential organization of actions versus the distribution of voiced content across agents), but share a common social constructionist critique of authority as something that is obviously located in particular persons or roles.

\section{References}

Atkinson, J. M. (1982). Understanding formality: The categorization and production of "formal" interaction. British Journal of Sociology, 33, 86-117.

Bakhtin, M. M., \& Emerson, C. (1993). Problems of Dostoevsky's poetics. Minneapolis, MN: University of Minnesota.

Bartesaghi, M. (2009). How the therapist does authority: Six strategies for substituting client accounts in the session. Communication \& Medicine, 6, 15-25. doi: 10.1558.cam.v5i2.15.

Benoit-Barné, C., \& Cooren, F. (2009). The accomplishment of authority through presentification: How authority is distributed among and negotiated by organizational members. Management Communication Quarterly, 23(1), 5-31. https://doi.org/10.1177\%2F0893318909335414

Cameron, D. (2001). Working with spoken discourse. Thousand Oaks, CA: Sage. 
Castor, T., \& Cooren, F. (2006). Organizations as hybrid forms of life: The implications of the selection of agency in problem formulation. Management Communication Quarterly, 19(4), 570-600. https://doi.org/10.1177\%2F089 3318905284764

Chiang, S. Y. (2015). Power and discourse. In K. Tracy, C. Ilie, \& T. Sandel (Eds.), The international encyclopedia of language and social interaction (pp. 1-17). Boston, MA: John Wiley \& Sons. doi: 10.1002/9781118611463.wbielsi149.

Cooren, F. (2006). The organizational world as a plenum of agencies. In F. Cooren, J. R. Taylor, \& E. J. Van Every (Eds.), Communication as organizing: Empirical and theoretical explorations in the dynamic of text and conversation (pp. 81-100). Mahwah, NJ: Lawrence Erlbaum.

Cooren, F. (2010). Action and agency in dialogue: Passion, incarnation and ventriloquism. Amsterdam: John Benjamins Publishing Company.

Cooren, F. (2011, May). Figures in tension in organizational communication. Paper presented at the 61st Annual Conference of the International Communication Association, Boston, MA.

Drew, P., \& Heritage, J. (1992). Analyzing talk at work: An introduction. In P. Drew \& J. Heritage (Eds.), Talk at work (pp. 3-65). Cambridge, UK: Cambridge University Press.

Gardner, R. (2013). Conversation analysis in a classroom. In J. Sidnell \& T. Stivers (Eds.), The handbook of conversation analysis (pp. 593-611). Oxford, UK: Blackwell Publishing Ltd.

Goodwin, M. H. (1990). He-said-she-said: Talk as social organization among Black children. Bloomington, IN: Indiana University Press.

Griswold, O. (2007). Achieving authority: Discursive practices in Russian girls' pretend play. Research on Language and Social Interaction, 40, 291-319. https://doi.org/10.1080/08351810701471286

Gumperz, J. J. (1999). On interactional sociolinguistic method. In S. Sarangi \& C. Roberts (Eds.), Talk, work and institutional order: Discourse in medical, mediation and management settings (pp. 453-471). Berlin and New York, NY: Mouton de Gruyter.

Hepburn, A., \& Bolden, G. B. (2013). The conversation analytic approach to transcription. In J. Sidnell \& T. Stivers (Eds.), The handbook of conversation analysis (pp. 57-76). Oxford, UK: Blackwell Publishing.

Heritage, J. (1988). Explanations as accounts: A conversation analytic perspective. In C. Antaki (Ed.), Understanding everyday explanation: A casebook of methods (pp. 127-144). Beverly Hills, CA: Sage.

Heritage, J. (2005). Conversation analysis and institutional talk. In K. Fitch \& R. Sanders (Eds.), Handbook of language and social interaction (pp. 103-147). Hove, UK: Psychology Press.

Heritage, J., \& Raymond, G. (2005). The terms of agreement: Indexing epistemic authority and subordination in talk-in-interaction. Social Psychology Quarterly, 68, 15-38. https://doi.org/10.1177\%2F019027250506800103

Hutchby, I. (1996). Confrontation talk: Arguments, asymmetries, and power on talk radio. Mahwah, NJ: Lawrence Erlbaum Associates, Publishers.

Ilie, C. (2003). Discourse and metadiscourse in parliamentary debates. Journal of Language and Politics, 2(1), 71-92. https://doi.org/10.1075/jlp.2.1.05ili

Koschmann, M. A., \& Burk, N. R. (2016). Accomplishing authority in collaborative work. Western Journal of Communication, 80, 393-413. https://doi.org/1 0.1080/10570314.2016.1159728 
Koschmann, M. A., Kopczynsky, J., Opdyke, A., \& Javernick-Will, A. (2017). Constructing authority in disaster relief coordination. The Electronic Journal of Communication/La Review Electronic de Communication, 27, 1-24.

Maoz, I., \& Ellis, D. G. (2001). Going to ground: Argument in Israeli-Jewish and Palestinian encounter groups. Research on Language and Social Interaction, 34, 399-419. https://doi.org/10.1207/S15327973RLSI3404_01

Mondada, L. (2011). The management of knowledge discrepancies and of epistemic changes in institutional interactions. In T. Stivers, L. Mondada, \& J. Steensig (Eds.), The morality of knowledge in conversation (pp. 27-57). Cambridge, UK: Cambridge University Press.

Pomerantz, A., \& Denvir, P. (2007). Enacting the institutional role of chairperson in upper management meetings: The interactional realization of provisional authority. In F. Cooren (Ed.), Interacting and organizing: Analyses of a management meeting (pp. 31-51). Mahwah, NJ: Lawrence Erlbaum Associates, Publishers.

Reynolds, E. (2011). Enticing a challengeable in arguments. Pragmatics: Quarterly Publication of the International Pragmatics Association (IPrA), 21(3), 411-430. https://doi.org/10.1075/prag.21.3.06rey

Robles, J. S., \& Castor, T. (2019). Taking the moral high ground: Practices for being uncompromisingly principled. Journal of Pragmatics, 141, 116-129. https://doi.org/10.1016/j.pragma.2018.12.015

Sacks, H., Schegloff, E. A., \& Jefferson, G. (1974). A simplest systematics for the organization of turn-taking for conversation. Language, 50, 696-735.

Sacks, H., Schegloff, E. A., \& Jefferson, G. (1977). The preference of selfcorrection in the organization of repair in interaction. Language, 53, 361-382.

Schegloff, E. A. (1992). Repair after next turn: The last structurally provided defense of intersubjectivity in conversation. American Journal of Sociology, 97(5), 1295-1345.

Schegloff, E. A. (2007). Sequence organization in interaction: Volume 1: A primer in conversation analysis (Vol. 1). New York, NY: Cambridge University Press.

Stevanovic, M., \& Peräkylä, A. (2012). Deontic authority in interaction: The right to announce, propose, and decide. Research on Language and Social Interaction, 45, 297-321. https://doi.org/10.1080/08351813.2012.699260

Taylor, J. R., \& Van Every, E. J. (2000). The emergent organization: Communication as site and surface. Mahwah, NJ: Lawrence Erlbaum Associates, Publishers.

Taylor, J. R., \& Van Every, E. J. (2014). When organization fails: Why authority matters. New York, NY: Routledge.

Tracy, K. (2001). Discourse analysis in communication. In D. Schiffrin, D. Tannen, \& H. E. Hamilton (Eds.), The handbook of discourse analysis (pp. 725-749). Malden, MA: Blackwell.

Tracy, K., \& Spradlin, A. (1994). “Talking like a mediator”: Conversational moves of experienced divorce mediators. In J. P. Folger \& T. S. Jones (Eds.), New directions in mediation: Communication research and perspectives (pp. 110-132). Thousand Oaks, CA: Sage.

Van Dijk, T. A. (2004). Text and context of parliamentary debates. In P. Bayley (Ed.), Crosscultural perspective on parliamentary discourse (pp. 339-372). Amsterdam: John Benjamins Publishing Company.

Weber, M. (1958). The three types of legitimate rule. Berkeley Publications in Society and Institutions, 4(1), 1-11. 
Hence, working on this chapter was an exercise in appreciating the multi-dimensional nature of social interaction. The introduction to this chapter enumerated what we came to believe we shared: a deep commitment to where and how social phenomena are embodied and practiced. First, Boivin's looking for how we are ventriloquized by the voices of others questions who we really are. Second, Buttny tells us how authority is communicated. Third, as a critical scholar, Krippendorff argues that the exertion of authority implies submission. Holding authorities accountable can disrupt routine exertions of power and create spaces of possibilities that are normatively denied. He also links human agency to such socially constructed spaces which are continuously established as real. Aggerholm and Asmuß's emphasis on routine practices of authority in organizations highlights what we mindlessly do by playing our roles in various organizations. All in all, the encounter we examined demonstrated how routines can be shaken and the claim to be a mere puppet of someone or something else can be questioned, encouraging us to become aware of what we can do. Finally, in view of our analyses of how authority and power are negotiated, Krippendorff reminds us that we cannot escape issues of scientific authority. Not only do we have to provide accounts of our scholarship to our academic communities, we are also accountable to those we theorize, who benefit or may be harmed by our analyses, and to be consistent with our concerns, we also have to refrain from employing explanatory frameworks that leave those described no choice but to comply.

\section{References and Further Readings}

Aggerholm, H. K., \& Asmuß, B. (2016). When "good” is not good enough: Power dynamics and performative aspects of organizational routines. In J. HowardGrenville, C. Rerup, A. Langley, \& H. Tsoukas (Eds.), Perspectives on process organization studies (pp. 140-178). Oxford: Oxford University Press.

Bateson, G. (2000). Steps to an ecology of mind. Chicago, IL: University of Chicago Press.

Boden, D. (1994). The business of talk: Organizations in action. Cambridge: Polity Press.

Buttny, R. (1993). Social accountability in communication. London: Sage.

Buttny, R. (2014). Accounting research. In W. Donsbach (Ed.), The concise encyclopedia of communication. Oxford: Blackwell Publishing Ltd.

Buttny, R., \& Morris, G. H. (2001). Accounting. In W. P. Robinson \& H. Giles (Eds.), The new handbook on language and social psychology (pp. 285-302). New York: John Wiley \& Sons.

Cooren, F. (2010). Action and agency in dialogue: Passion, incarnation and ventriloquism. Philadelphia: John Benjamins Publishing.

Cooren, F. (2012). Communication theory at the center: Ventriloquism and the communicative constitution of reality. Journal of Communication, 62(1), 1-20.

Dionysiou, D. D., \& Tsoukas, H. (2013). Understanding the (re)creation of routines from within: A symbolic interactionist perspective. Academy of Management Review, 38(2), 181-205. 
Feldman, M. S. (2000). Organizational routines as a source of continuous change. Organization Science, 11, 611-629.

Feldman, M. S., \& Pentland, B. T. (2003). Reconceptualizing organizational routines as a source of flexibility and change. Administrative Science Quarterly, 48(1), 94-118.

Goodwin, C. (2018). Co-operative action. New York: Cambridge University Press.

Hall, S. (2001). Foucault: Power, knowledge and discourse. In M. Wetherell, S. Taylor, \& S. J. Yates (Eds.), Discourse theory and practice, a reader (pp. 72-81). Thousand Oaks, CA: Sage.

Jefferson, G. (2004). Glossary of transcript symbols with an introduction. In G. H. Lerner (Ed.), Conversation analysis: Studies from the first generation (pp. 13-31). Amsterdam: John Benjamins.

Krippendorff, K. (1991). The power of communication and the communication of power; Toward an emancipatory theory of communication. Communication, 12, 175-196.

Krippendorff, K. (2009). On communicating, otherness, meaning, and information. New York: Routledge.

Krippendorff, K. (2017). Three concepts to retire. Annals of the International Communication Association, 41(1), 92-99. doi: 10.1080/23808985.2017.1291281

Krippendorff, K. (2019). Content analysis: An introduction to its methodology (4th edition). Thousand Oaks, CA: Sage.

Lammers, J. C., \& Barbour, J. B. (2006). An institutional theory of organizational communication. Communication Theory, 16(3), 356-377.

Latour, B. (2005). Reassembling the social: An introduction to actor-networktheory. Oxford: Oxford University Press.

LeBaron, C. (2008). Microethnography. In K. Tracy (Ed.), The international encyclopedia of communication. Cambridge: Blackwell.

Mills, C. W. (1940). Situated actions and vocabularies of motive. American Sociological Review, 5(1), 904-913.

Putnam, L. L., \& Nicotera, A. M. (2009). Building theories of organization: The constitutive role of communication. New York: Routledge.

Sacks, H. (1992). Lectures on conversation. Oxford: Blackwell.

Sacks, H., Schegloff, E. A., \& Jefferson, G. (1974). A simplest systematics for the organization of turn-taking for conversation. Language, 50(4), 696-735.

Schegloff, E. A., Jefferson, G., \& Sacks, H. (1977). The preference for self correction in the organization of repair in conversation. Language, 53(2), 361-382.

Scott, M. B., \& Lyman, S. M. (1968). Accounts. American Sociological Review, $33(1), 46-62$.

Shotter, J. (1984). Social accountability and selfhood. Oxford: Basil Blackwell.

Sidnell, J., \& Stivers, T. (Eds.). (2013). The handbook of conversation analysis. Cambridge: Wiley-Blackwell.

Stivers, T., \& Sidnell, J. (2005). Introduction: Multimodal interaction. Semiotica, 156, 1-20.

Wright, A. (2016). Organizational routines as embodied performatives: A communication as constitutive of organization perspective. Organization, 23(2), 147-163. 
It is this game of expression that the ventriloquial analysis helps us decipher and analyze.

\section{Conclusion}

The three analytical perspectives presented above share a commitment to decenter the analysis towards the "things"-whether physical objects or seemingly abstract entities-that are active in the situation. In Vincent Denault and Pierrich Plusquellec's proposal, insights from experimental research comfort the analyst's recognition of facial expressions, which are then compared to verbal statements and actions from their owner. In that sense, facial expressions may challenge the speakers' other expressive modalities and reveal discrepancies between the authority they invoke and what actually drives them to say what they say or do what they do. Nicolas Bencherki and Alaric Bourgoin, for their part, suggest that things may participate in interaction irrespective of the interpretation people make of them. The meaning of their action proceeds from the contribution they make to broader activities. Since a same action may participate to several activities, it also has several meanings. Negotiating authority, then, consists in pointing out different activities to which action contributes, and therefore its very meaning. Finally, François Cooren and HueyRong Chen propose an analytical strategy based on the observation of the way people share the authorship of what they say and do with different figures, which are thus brought into the situation and presented as authorizing those actions, thus sharing their authority with the speaker.

\section{References}

Althusser, L. (1971). Ideology and ideological state apparatuses: Notes towards an investigation. In "Lenin and philosophy" and other essays (pp. 121-176). New York, NY: Monthly Review Press.

Ashenfelter, K. T. (2007). Simultaneous analysis of verbal and nonverbal data during conversation: Symmetry and turn-taking. Notre Dame, IN: University of Notre Dame.

Benoit-Barné, C., \& Cooren, F. (2009). The accomplishment of authority through presentification: How authority is distributed among and negotiated by organizational members. Management Communication Quarterly, 23(1), 5-31.

Brassac, C., Fixmer, P., Mondada, L., \& Vinck, D. (2008). Interweaving objects, gestures, and talk in context. Mind, Culture, and Activity, 15(3), 208-233. https://doi.org/10.1080/10749030802186686

Burgoon, J. K., \& Dunbar, N. (2006). Nonverbal expressions of dominance and power in human relationships. In V. Manusov \& M. L. Patterson (Eds.), The SAGE Handbook of Nonverbal Communication (pp. 279-297). Thousand Oaks, CA: Sage.

Burgoon, J. K., Guerrero, L. K., \& Floyd, K. (2010). Nonverbal communication. Boston: Pearson. 
Cooren, F. (2010). Action and agency in dialogue: Passion, ventriloquism and incarnation. Amsterdam and Philadelphia: John Benjamins Publishing Company.

Cooren, F., \& Bencherki, N. (2010). How things do things with words: Ventriloquism, passion and technology. Encyclopaideia, Journal of Phenomenology and Education, (28), 35-61.

Cooren, F., \& Matte, F. (2010). For a constitutive pragmatics: Obama, Médecins Sans Frontières and the measuring stick. Pragmatics and Society, 1(1), 9-31. https://doi.org/10.1075/ps.1.1.02coo

Cooren, F., Matte, F., Benoit-Barné, C., \& Brummans, B. H. J. M. (2013). Communication as Ventriloquism: A grounded-in-action approach to the study of organizational tensions. Communication Monographs, 80(3), 255-277. https:// doi.org/10.1080/03637751.2013.788255

Darwin, C. (1872). The expression of emotion in man and animals. New York: Oxford University Press.

Davis, K. (2018). Under God's authority: The Kim Davis story. Orlando, FL: New Revolution Publishers.

de Lemus, S., Spears, R., \& Moya, M. (2012). The power of a smile to move you: Complementary submissiveness in women's posture as a function of gender salience and facial expression. Personality and Social Psychology Bulletin, 31(11), 1480-1494.

Dean, L. M., Willis, F. N., \& Hewitt, J. (1975). Initial interaction distance among individuals equal and unequal in military rank. Journal of Personality and Social Psychology, 32(2), 294-299. http://dx.doi.org/10.1037/0022-3514.32.2.294

Derrida, J. (1994). Specters of Marx: The state of the debt, the work of mourning, and the new international. New York: Routledge.

Du, S., \& Martinez, A. M. (2015). Compound facial expressions of emotion: From basic research to clinical applications. Dialogues in Clinical Neuroscience, 17(4), 443-455.

Duchenne de Boulogne, G. (1862/1990). Mécanisme de la physionomie humaine. Paris: Jules Renouard.

Ekman, P. (1965). Communication through nonverbal behavior: A source of information about an interpersonal relationship. In S. S. Tomkins \& C. E. Izard (Eds.), Affect, cognition and personality (pp. 389-442). New York: Springer.

Ekman, P. (2003). Emotions revealed. New York: Henry Holt.

Ekman, P. (2016). What scientists who study emotion agree about. Perspectives on Psychological Science, 11(1), 31-34. https://doi.org/10.1177/17456 91615596992

Ekman, P., \& Friesen, W. (1978). Facial action coding system: A technique for the measurement of facial movement. Palo Alto, CA: Consulting Psychologists Press.

Foucault, M. (1995). Discipline and punish: The birth of the prison. New York: Vintage Books. (Original work published 1977).

Garfinkel, H. (1967). Studies in ethnomethodology. Englewood Cliffs, NJ: Prentice-Hall.

Garfinkel, H. (1996). Ethnomethodology's program. Social Psychology Quarterly, 59(1), 5-21.

Geertz, C. (1973). Thick description: Toward an interpretive theory of culture. In The interpretation of cultures: Selected essays (pp. 3-30). New York, NY: Basic Books. 
Goodwin, C. (1980). Restarts, pauses, and the achievement of mutual gaze at turnbeginning. Sociological Inquiry, 50(3-4), 272-302. https://doi.org/10.1111/ j.1475-682X.1980.tb00023.x

Goodwin, C., \& Heritage, J. (1990). Conversation analysis. Annual Review of Anthropology, 19, 283-307.

Hall, E. T. (1959). The silent language. Garden City: Anchor

Hall,E.T.(1963).A system for the notation of proxemic behavior. American Anthropologist, 65(5), 1003-1026. https://doi.org/10.1525/aa.1963.65.5.02a00020

Hall, J. A., Coats, E., \& Smith LeBeau, L. (2005). Nonverbal behavior and the vertical dimension of social relations: A meta-analysis. Psychological Bulletin, 131(6), 898-924. https://doi.org/10.1037/0033-2909.131.6.898

Harrigan, J. A. (2005). Proxemics, kinesics, and gaze. In J. A. Harrigan, R. Rosenthal \& K. R. Scherer (Eds.), The new handbook on methods in nonverbal behavior research (pp. 137-198). Oxford: Oxford University Press.

Hecht, M. A., \& LaFrance, M. (1998). License or obligation to smile: The effect of power and sex on amount and type of smiling. Personality and Social Psychology Bulletin, 24(12), 1332-1342. http://dx.doi.org/10.1177/01461672982412007

Hess, U., Blairy, S., \& Kleck, R. E. (2000). The influence of facial emotion displays, gender, and ethnicity on judgments of dominance and affiliation. Journal of Nonverbal Behavior, 24(4), 265-283. https://doi.org/10.1023/A:1006623213355

Hindmarsh, J., \& Heath, C. (2003). Transcending the object in embodied interaction. In J. Coupland \& R. Gwyn (Eds.), Discourse, the body, and identity (pp. 43-69). London: Palgrave Macmillan. https://doi.org/10.1057/978140 3918543_3

Kaukomaa, T., Peräkylä, A., \& Ruusuvuori, J. (2015). How listeners use facial expression to shift the emotional stance of the speaker's utterance. Research on Language and Social Interaction, 48(3), 319-341. https://doi.org/10.1080/083 51813.2015.1058607

Kendrick, K. H. (2017). Using conversation analysis in the lab. Research on Language and Social Interaction, 50(1), 1-11. https://doi.org/10.1080/08351813. 2017.1267911

Knutson, B. (1996). Facial expressions of emotion influence interpersonal trait inferences. Journal of Nonverbal Behavior, 20(3), 165-182.

Koschmann, T., \& Zemel, A. (2011). "So that's the ureter": The informal logic of discovering work. Ethnographic Studies, 12, 31-46.

Latour, B. (1992). Where are the missing masses? The sociology of a few mundane artifacts. In W. E. Bijker \& J. Law (Eds.), Shaping technology/building society: Studies in sociotechnical change (pp. 225-258). Cambridge, MA: MIT Press.

Latour, B. (1996). On interobjectivity. Mind, Culture, and Activity, 3(4), 228245. https://doi.org/10.1207/s15327884mca0304_2

Mondada, L. (2007). Multimodal resources for turn-taking: Pointing and the emergence of possible next speakers. Discourse Studies, 9(2), 194-225. https:// doi.org/10.1177/1461445607075346

Mondada, L. (2009). Emergent focused interactions in public places: A systematic analysis of the multimodal achievement of a common interactional space. Journal of Pragmatics, 41(10), 1977-1997.https://doi.org/10.1016/j.pragma.2008.09.019

Nevile, M., Haddington, P., Heinemann, T., \& Rauniomaa, M. (Eds.). (2014). Interacting with objects: Language, materiality, and social activity. Amsterdam and Philadelphia: John Benjamins Publishing Company. 


\section{Nicolas Bencherki, Alaric Bourgoin, et al.}

Plusquellec, P., \& Denault, V. (2018). The 1000 most cited papers on visible nonverbal behavior: A bibliometric analysis. Journal of Nonverbal Behavior, 42(3), 347-377.

Remland, M. (1981). Developing leadership skills in nonverbal communication: A situational perspective. Journal of Business Communication, 18, 18-31. https://doi.org/10.1177/002194368101800303

Simondon, G. (2005). L'individuation à la lumière des notions de forme et d'information. Grenoble: Jérôme Millon. (Original work published 1958).

Stivers, T., \& Sidnell, J. (2005). Introduction: Multimodal interaction. Semiotica, 156, 1-20. https://doi.org/10.1515/semi.2005.2005.156.1

Taylor, J. R., \& Van Every, E. J. (2000). The emergent organization. Communication as site and surface. Mahwah, NJ: Lawrence Erlbaum Associates.

Taylor, J. R., \& Van Every, E. J. (2014). When organization fails: Why authority matters. New York: Routledge.

Vásquez, C. (2016). A spatial grammar of organising: Studying the communicative constitution of organisational spaces. Communication Research and Practice, 2(3), 351-377. https://doi.org/10.1080/22041451.2016.1221686

Zemel, A., \& Koschmann, T. (2016). A stitch in time: Instructing temporality in the operating room. Communication \& Medicine, 12(1), 85-98. https://doi. org/10.1558/cam.v12i1.25988 


\section{Bertrand Fauré, Thomas Martine, et al.}

\section{Note}

1. In this section, we capitalize the word Love to stress the parity between God and Love.

\section{References}

Aakhus, M., Ballard, D., Flanagin, A. J., Kuhn, T., Leonardi, P., Mease, J., \& Miller, K. (2011). Communication and materiality: A conversation from the CM cafe'. Communication Monographs, 78(4), 557-568. https://doi.org/10.10 80/03637751.2011.618358

Arendt, H. (1994). Eichmann in Jerusalem. New York, NY: Penguin Books.

Barad, K. (2007). Meeting the universe halfway: Quantum physics and the entanglement of matter and meaning. Durham, NC: Duke University Press.

Basso, K. (1996). Wisdom sits in places: Landscape and language among the Western Apache. Albuquerque, NM: University of New Mexico Press.

Benoit-Barné, C., \& Cooren, F. (2009). The accomplishment of authority through presentification: How authority is distributed among and negotiated by organizational members. Management Communication Quarterly, 23(1), 5-31. https://doi.org/10.1177/0893318909335414

Blommaert, J. (2009). Ethnography and democracy: Hymes's political theory of language. Text \& Talk, 29(3), 257-276. https://doi.org/10.1515/TEXT. 2009.014

Carbaugh, D. (1988/1989). Deep agony: "Self” vs. "society" in Donahue discourse. Research on Language and Social Interaction, 22, 179-212. https://doi.org/ 10.1080/08351818809389302

Carbaugh, D. (1995). “Are Americans really superficial?”: Notes on Finnish and American cultures in linguistic action. In L. Salo-Lee (Ed.), Kieli \& julttuuri (pp. 269-297). Jyvaskyla, Finland: Publications of the Department of Communication, University of Jyvaskyla.

Carbaugh, D. (1999). "Just listen": "Listening" and landscape among the Blackfeet. Western Journal of Communication, 63(3), 250-270. https://doi.org/10.1080/ 10570319909374641

Carbaugh, D. (2007). Cultural discourse analysis: Communication practices and intercultural encounters. Journal of Intercultural Communication Research, 36(3), 167-182. https://doi.org/10.1080/17475750701737090

Carbaugh, D., Berry, M., \& Numikari-Berry, M. (2006). Coding personhood through cultural terms and practices: Silence and quietude as a Finnish "natural way of being". Journal of Language and Social Psychology, 25, 203-220. https://doi.org/10.1177/0261927X06289422

Cooren, F. (2012). Communication theory at the center: Ventriloquism and communicative construction of reality. Journal of Communication, 62, 1-20. https:// doi.org/10.1111/j.1460-2466.2011.01622.x

Cooren, F. (2015). In medias res: Communication, existence, and materiality. Communication Research and Practice, 1(4), 307-321. https://doi.org/10.108 0/22041451.2015.1110075

Cooren, F., \& Sandler, S. (2014). Polyphony, ventriloquism, and constitution: In dialogue with Bakhtin. Communication Theory, 24(3), 225-244. https://doi. org/10.1111/comt.12041 
Covarrubias, K., \& Saito, M. (2019). Symbolic agonistics: Stressing emotion and relation in Mexican, Mexican@, and Japanese discourses. In M. Scollo \& T. Milburn (Eds.), Engaging and transforming global communication through cultural discourse analysis: A tribute to Donal Carbaugh. Madison, NJ: Farleigh Dickinson Press.

Covarrubias, P. O., \& Windchief, S. R. (2009). Silences in stewardship: Some American Indian college student examples. The Howard Journal of Communication, 20(4), 333-352. https://doi.org/10.1080/10646170903300754

Davis, K., Aman, J., \& Staver, M. (2018). Under God's authority: The Kim Davis story. Maitland, FL: Liberty Counsel.

Fiske, J. (1990). Review of talking American: Cultural discourses on Donahue by D. Carbaugh. Quarterly Journal of Speech, 76, 450-451. https://doi.org/ $10.1080 / 00335639009383936$

Fiske, J. (1991). Writing ethnographies: Contribution to a dialogue. Quarterly Journal of Speech, 77, 330-335. https://doi.org/10.1080/00335639109383964

Hoopes, J. (Ed.). (1991). Peirce on signs: Writing on semiotic. Chapel Hill, NC: University of North Carolina Press.

Hymes, D. (1973). Speech and language: On the origins and foundations of inequality among speakers. Daedalus, 102(3), 59-85.

Hymes, D. (1974). Foundations in sociolinguistics: An ethnographic approach. Philadelphia, PA: University of Pennsylvania Press.

Latour, B. (2013). An inquiry into modes of existence: An anthropology of the moderns. Cambridge, MA: Harvard University Press.

Martine, T., \& Cooren, F. (2016). A relational approach to materiality and organizing: The case of a creative idea. In Beyond interpretivism? New encounters with technology and organization (p. 143-166). Cham: Springer. https://doi. org/10.1007/978-3-319-49733-4_9

Martine, T., Cooren, F., \& Bartels, G. (2017). Evaluating creativity through the degrees of solidity of its assessment: A relational approach. The Journal of Creative Behavior. https://doi.org/10.1002/jocb.219

Milstein, T. (2008). When whales "speak for themselves": Communication as a mediating force in wildlife tourism. Environmental Communication, 2(2), 173-192. https://doi.org/10.1080/17524030802141745

Molina-Markham, E. (2012). Lives that preach: The cultural dimensions of telling one's “spiritual journey” among Quakers. Narrative Inquiry, 22(1), 3-23. https://doi.org/10.1075/ni.22.1.02mol

Philipsen, G. (1986). Mayor Daley's council speech: A cultural analysis. Quarterly Journal of Speech, 72, 247-260. https://doi.org/10.1080/003356386093 83772

Putnam, L., \& Nicotera, A. M. (Ed.). (2009). Building theories of organization: The constitutive role of communication. New York, NY: Routledge.

Scollo, C., \& Milburn, T. (Eds.). (2019). Engaging and transforming global communication through cultural discourse analysis: A tribute to Donal Carbaugh. Madison, NJ: Farleigh Dickinson Press.

Scollo, M. (2004). Nonverbal ways of communicating with nature: A cross-case study. In S. L. Senecah (Ed.), The environmental communication yearbook (pp. 227-249). Mahwah, NJ: Lawrence Erlbaum.

Scollo, M. (2011). Cultural approaches to discourse analysis: A theoretical and methodological conversation with special focus on Donal Carbaugh's cultural 


\section{Bertrand Fauré, Thomas Martine, et al.}

discourse theory. Journal of Multicultural Discourses, 6(1), 1-32. https://doi. org/10.1080/17447143.2010.536550

Taylor, J. R., \& Cooren, F. (1997). What makes communication “organizational” ? How the many voices of a collectivity become the one voice of an organization. Journal of Pragmatics, 27, 409-438. https://doi.org/10.1016/S0378-2166 (96)00044-6

Taylor, J. R., \& Van Every, E. (2014). When organization fails: Why authority matters. New York, NY: Routledge.

Tracy, K. (2009). How questioning constructs judge identities: Oral argument about same-sex marriage. Discourse Studies, 11(2), 199-221. https://doi.org/10.1177/ 1461445608100944

Tracy, K., \& Hughes, J. M. F. (2014). Democracy-appealing partisanship: A situated ideal of citizenship. Journal of Applied Communication Research, 42(3), 307-324. doi: 10.1080/00909882.2014.911940

van Over, B. (n.d.). The cultural boundaries of the sayable: Three codes for the use and interpretation of claims of the inexpressible. Unpublished conference paper.

van Over, B., Dori-Hacohen, G., \& Winchatz, M. (2019). Policing the boundaries of the sayable: The public negotiation of profane, prohibited and proscribed speech. In M. Scollo \& T. Milburn (Eds.), Engaging and transforming global communication through cultural discourse analysis: A tribute to Donal Carbaugh. Madison, NJ: Farleigh Dickinson Press. 
in the establishment of authority, thus contributing to a more thorough understanding of the phenomenon.

All the approaches in this chapter agree that authority is a dynamic and fluid phenomenon that is constructed and negotiated in social interactions, even by agents that remain invisible, marginal or unspecified. Each perspective, however, differs in focus and emphasis. According to Benoit-Barné, authority is relational, emerging in social interaction through presentification, a communicative process by which agents cocreate and negotiate the emergence of authority. For Marsen, authority is discursive, manifesting in the positioning of agents and the description of their actions and words by an orchestrating presenter, or narrator. In Yang's analysis, power and authority relates to widely shared assumptions (for instance, the idea of "media power"), but their enactment largely depends on situational construction of relationships and identities. Finally, Wang follows a conversation analytic approach that explicates how authority is socially constructed through interactants' exchange of social actions and their orientations toward the social relations embodied in their actions. Table 6.1 provides an overview of what characterizes the four approaches.

\section{References}

Bal, M. (1993). First person, second person, same person: Narrative as epistemology. New Literary History, 24, 293-320.

Barthes, R. (1977). The death of the author. Image/Music/Text (S. Heath, Trans., pp. 142-147). New York: Hill and Wang. (Original work published 1967).

Benoit-Barné, C., \& Cooren, F. (2009). The accomplishment of authority through presentification: How authority is distributed among and negotiated by organizational members. Management Communication Quarterly, 23(1), 5-31.

Benoit-Barné, C., \& Fox, S. (2017). Authority. In C. Scott \& L. Lewis (Eds.), The international encyclopedia of organizational communication. New York: Wiley-Blackwell.

Bourdieu, P. (1991). Language and symbolic power. Cambridge, MA: Harvard University Press.

Breiger, R. L. (2000). A tool kit for practice theory. Poetics, 27(2-3), 91-115.

Cammaerts, B., Mattoni, A., \& McCurdy, P. (Eds.). (2013). Mediation and protest movements. New York: Intellect Books.

Castells, M. (1997). The power of identity. Oxford, England: Blackwell.

Chatman, S. (1978). Story and discourse: Narrative structure in fiction and film. Ithaca, NY: Cornell University Press.

Cooren, F. (2006). The organizational world as a plenum of agencies. In F. Cooren, J. R. Taylor, \& E. J. Van Every (Eds.), Communication as organizing: Empirical and theoretical explorations in the dynamic of text and conversation (pp. 81-100). Mahwah, NJ: Lawrence Erlbaum.

Cooren, F., Brummans, H. J. M., \& Charrieras, D. (2008). The coproduction of organizational presence: A study of Médecins Sans Frontières in action. Human Relations, 61(10), 1339-1370. 
Couldry, N. (2001). The hidden injuries of media power. Journal of Consumer Culture, 1(2), 155-177.

Couldry, N. (2002). The place of media power: Pilgrims and witnesses of the media age. London: Routledge.

Couldry, N., \& Curran, J. (Eds.). (2003). Contesting media power: Alternative media in a networked world. Boulder, CO: Rowman \& Littlefield.

Couldry, N., \& Hepp, A. (2013). Conceptualizing mediatization: Contexts, traditions, arguments. Communication Theory, 23(3), 191-202.

Curran, J. (2002). Media and power. London: Routledge.

Drew, P. (2012). Turn design. In The handbook of conversation analysis (pp. 131149). Oxford, UK: Wiley-Blackwell. https://doi.org/10.1002/9781118325001.ch7

Drew, P., \& Heritage, J. (1992). Talk at work: Interaction in institutional settings. Cambridge, UK: Cambridge University Press.

Eliasoph, N., \& Lichterman, P. (2003). Culture in interaction. American Journal of Sociology, 108(4), 735-794.

Genette, G. (1983). Narrative discourse: An essay in method. (J. E. Lewin, Trans.). New York: Cornell University Press. (Original work published 1978).

Greimas, A. J. (1987). On meaning: Selected writings in semiotic theory. (P. J. Perron \& F. H. Collins, Trans.). Minneapolis, MN: University of Minnesota Press. (Original work published 1983).

Gumbrecht, H. U. (2004). Production of presence: What meaning cannot convey. Stanford, CA: Stanford University Press.

Hayashi, M. (2012). Turn allocation and turn sharing. In J. Sidnell \& T. Stivers (Eds.), The handbook of conversation analysis (pp. 167-190). Oxford, UK: Wiley-Blackwell. https://doi.org/10.1002/9781118325001.ch9

Heritage, J. (1984). Garfinkel and ethnomethodology. Cambridge, UK: Polity Press.

Herman, D. (2009). Basic elements of narrative. Oxford, UK: Wiley Blackwell.

Jahn, M. (2001). Narrative voice and agency in drama: Aspects of a narratology of drama. New Literary History, 32, 659-679.

Lichterman, P., \& Eliasoph, N. (2014). Civic action. American Journal of Sociology, 120(3), 798-863.

Livingstone, S. (2009). On the mediation of everything: ICA presidential address 2008. Journal of communication, 59(1), 1-18.

Marsen, S. (2006). Narrative dimensions of philosophy. London: Palgrave.

McCurdy, P. (2011). Theorizing lay theories of media: A case study of the dissent! Network at the 2005 Gleneagles G8 Summit. International Journal of Communication, 5, 619-638.

McCurdy, P. (2012). Social movements, protest and mainstream media. Sociology Compass, 6(3), 244-255.

Melucci, A. (1996). Challenging codes: Collective action in the information age. Cambridge, UK: Cambridge University Press.

Pomerantz, A., \& Mandelbaum, J. (2004). Conversation analytic approaches to the relevance and uses of relationship categories in interaction. In K. L. Fitch \& R. E. Sanders (Eds.), Handbook of language and social interaction. New York, NY: Routledge Handbooks Online. https://doi.org/10.4324/9781410611574.ch6

Prince, G. (2003). Surveying narratology. In T. Kindt \& H.-H. Muller (Eds.), What is narratology? Questions and answers regarding the status of a theory (pp. 1-16). Berlin and New York: Walter de Gruyter. 
Reed, I. A. (2013). Power: Relational, discursive, and performative dimensions. Sociological Theory, 31(3), 193-218.

Reed, I. A. (2017). Chains of power and their representation. Sociological Theory, 35(2), 87-117.

Robinson, J. D. (2012). Overall structural organization. In The handbook of conversation analysis (pp. 257-280). New York: Wiley-Blackwell. https://doi. org/10.1002/9781118325001.ch13

Rucht, D. (2004). The quadruple "A": Media strategies of protest movements since the 1960s. In W. van De Donk, B. Loader, P. Nixon, \& D. Rucht (Eds.), Cyberprotest: New media, citizens and social movements (pp. 29-56). London: Routledge.

Sacks, H., Schegloff, E., \& Jefferson, G. (1974). A simplest systematics for the organization of turn-taking for conversation. Language, 50, 696-735.

Schegloff, E. (2007). Sequence organization in interaction: A primer in conversation analysis. Cambridge: Cambridge University Press.

Stivers, T. (2012). Sequence organization. In The handbook of conversation analysis (pp. 191-209). New York: Wiley-Blackwell. https://doi.org/10.1002/ 9781118325001.ch10

Taylor, J., \& Van Every, E. J. (2014). When organization fails: Why authority matters. New York: Routledge.

Thompson, J. B. (1995). The media and modernity: A social theory of the media. Palo Alto, CA: Stanford University Press. 


\section{Appendix \\ Transcript of County Clerk Defying Supreme Court on Gay Marriage}

Video available at www.youtube.com/watch?v=ComaDQijgxA An alternate version is available at https://youtu.be/T7HNVEQ4OmU?t=376

This transcription is inspired by the method suggested by Gail Jefferson (2004) and which has come to be known as the Jeffersonian transcription convention. It allows to capture not only what is being said but also how.

For the purpose of this transcript, we use the following special symbols:

((double parentheses)) are used to describe non-verbal aspects of what goes on;

(.) (0.5) single parentheses with a dot or with a number in them indicate a brief pause of either a tenth of a second or the duration the numbers designate in seconds;

= equal signs at the end of a turn of talk and at the beginning of the next indicate that there was no break or gap between them;

A dash- following a word signals a cut-off or an unfinished word;

[ opening square brackets indicate where an overlap begins, with the aligned square brackets in the next line;

$\uparrow$ an upward arrow corresponds to a higher pitch, as is the case when ending a question, for instance;

$>$ right and left carats < bracket a portion of the talk that is speeded up; Colu:::ms indicate the preceding sound is prolongated;

Underlined words are stressed;

UPPERCASE words are told louder than normal, as when shouting; (xxx), (inaudible) or (word) indicate that the transcriber could not understand what was said or that there is uncertainty about that was actually said.

\section{Reference}

Jefferson, G. (2004). Glossary of transcript symbols with an introduction. In G. H. Lerner (Ed.), Conversation analysis: Studies from the first generation (pp. 13-31). Amsterdam and Philadelphia: John Benjamins Publishing Company. 